University of South Florida

DIGITAL COMMONS

Digital Commons @ University of

@ UNIVERSITY OF SOUTH FLORIDA

South Florida

\title{
Amazon River Water in the Northeastern Caribbean Sea and Its Effect on Larval Reef Fish Assemblages during April 2009
}

\author{
E. M. Johns \\ B. A. Muhling \\ R. C. Perez \\ Frank E. Muller-Karger \\ University of South Florida, carib@usf.edu \\ N. Melo
}

See next page for additional authors

Follow this and additional works at: https://digitalcommons.usf.edu/msc_facpub

Part of the Life Sciences Commons

\begin{abstract}
Scholar Commons Citation
Johns, E. M.; Muhling, B. A.; Perez, R. C.; Muller-Karger, Frank E.; Melo, N.; Smith, R. H.; Lamkin, J. T.; Gerard, T. L.; and Malca, E., "Amazon River Water in the Northeastern Caribbean Sea and Its Effect on Larval Reef Fish Assemblages during April 2009" (2014). Marine Science Faculty Publications. 1052. https://digitalcommons.usf.edu/msc_facpub/1052
\end{abstract}

This Article is brought to you for free and open access by the College of Marine Science at Digital Commons @ University of South Florida. It has been accepted for inclusion in Marine Science Faculty Publications by an authorized administrator of Digital Commons @ University of South Florida. For more information, please contact digitalcommons@usf.edu. 


\section{Authors}

E. M. Johns, B. A. Muhling, R. C. Perez, Frank E. Muller-Karger, N. Melo, R. H. Smith, J. T. Lamkin, T. L. Gerard, and E. Malca 


\section{Amazon River water in the northeastern Caribbean Sea and its effect on larval reef fish assemblages during April 2009}

\author{
E. M. JOHNS, ${ }^{1, *}$ B. A. MUHLING, ${ }^{2,3}$ \\ R. C. PEREZ, ${ }^{1,2}$ F. E. MÜLLER-KARGER, ${ }^{4}$ \\ N. MELO ${ }^{1,2}$ R. H. SMITH, ${ }^{1}$ J. T. LAMKIN ${ }^{3}$ \\ T. L. GERARD ${ }^{3}$ AND E. MALCA ${ }^{2,3}$ \\ ${ }^{1}$ NOAA Atlantic Oceanographic and Meteorological Laboratory, \\ 4301 Rickenbacker Causeway, Miami, FL, 33149, U.S.A. \\ ${ }^{2}$ Cooperative Institute for Marine and Atmospheric Studies, \\ University of Miami, Miami, FL, 33149, U.S.A. \\ ${ }^{3}$ NOAA National Marine Fisheries Service, Southeast Fisheries \\ Science Center, Miami, FL, 33149, U.S.A. \\ ${ }^{4}$ Institute for Marine Remote Sensing, College of Marine Science, \\ University of South Florida, St. Petersburg, FL, 33701, U.S.A.
}

\begin{abstract}
During April to June 2009, a large bolus of Amazon River water impacted the northeastern Caribbean Sea. Shipboard observations collected near Saba Bank, the U.S. and British Virgin Islands, and the Anegada Passage showed low surface salinity $(35.76 \pm 0.05$ Practical Salinity Unit (PSU)), elevated surface temperature $\left(26.77 \pm 0.14^{\circ} \mathrm{C}\right)$, high chlorophyll-a $\left(1.26 \pm 0.21 \mathrm{mg} \mathrm{m}^{-3}\right)$ and high dissolved oxygen $\left(4.90 \pm 0.06 \mathrm{~mL} \mathrm{~L}^{-1}\right)$ in a 20 - to 30 -m thick surface layer in the riverine plume. The water was $\sim 1^{\circ} \mathrm{C}$ warmer, 1 PSU fresher, $0.3 \mathrm{~mL} \mathrm{~L}^{-1}$ higher in oxygen and $1.2 \mathrm{mg} \mathrm{m}^{-3}$ higher in chlorophyll-a than Atlantic Ocean waters to the north, with Caribbean surface waters showing intermediate values. Plankton net tows obtained in the upper $100 \mathrm{~m}$ of the water column revealed larval fish assemblages within the plume that were significantly different from those of the surrounding waters and from those encountered in the area in previous years. The plume waters contained higher concentrations of mesopelagic fish larvae from the families Myctophidae and Nomeidae, which as adults typically inhabit offshore, deep water habitats. Concentrations of larvae from inshore and reef-associated families such as Scaridae, Serranidae, Labridae and Clupeidae were lower than those found outside the plume in similar shallow areas, particularly in near-
\end{abstract}

*Correspondence. e-mail: libby.johns@noaa.gov

Received 18 November 2013

Revised version accepted 30 June 2014 surface waters. An event like the one observed in 2009 had not been documented in at least the past $30 \mathrm{yr}$, and yet it was followed by another similarly extreme event in 2010. The ecological implications, including any long-term consequences of such recent extreme events, are important and merit further study.

Key words: Amazon River plume, Caribbean Sea, chlorophyll-a, hydrography, larval fish assemblages, North Brazil Current Ring, ocean color remote sensing

\section{INTRODUCTION}

Highly productive plumes of water from the Amazon and Orinoco Rivers spread from their sources into the western tropical Atlantic Ocean and eastern Caribbean Sea. These rivers combined represent nearly 20\% of the world's riverine input to the oceans. Their plumes are identifiable over great distances from shipboard observations and measurements from space by their low surface salinity and distinctive ocean color signatures, tracing surface circulation features in the tropical Atlantic and Caribbean Sea (e.g., Müller-Karger et al., 1988, 1989; Hu et al., 2004; Odriozola et al., 2007). In this paper we examine a major Amazon River plume event that took place from April to June 2009 in the northeastern Caribbean Sea, encompassing Saba Bank, the U.S. and British Virgin Islands, and Anegada Passage, markedly degrading the water column visibility and altering the surface water properties. Press reports indicated that such a 'green water' event had not been observed before. This event generated much local concern because of the ecological and economic importance of the coral reefs and reef fish to the islands.

Satellite ocean color images, published first in the 1980s (Müller-Karger et al., 1988) and many times since, show a strong seasonal cycle in the dispersal pattern of the Amazon River plume. Between about January and May, Amazon River water spreads directly from the equator northwestward along the coast of South America towards the Caribbean Sea (Fig. 1, orange line), trapped by the North Brazil Current (NBC), the Guiana Current and regional winds. Large volumes of Amazon River water carried by this coastal 
Figure 1. Schematic map of the western tropical Atlantic Ocean showing the typical seasonal positions of the Orinoco and Amazon River plumes from a SeaWiFS satellite ocean color climatology for January (orange line) and August (red line). Major ocean currents are also depicted. The white rectangle in the northeastern Caribbean Sea shows the April 2009 cruise study area, $17-19^{\circ} \mathrm{N}, 66-62^{\circ} \mathrm{W}$.

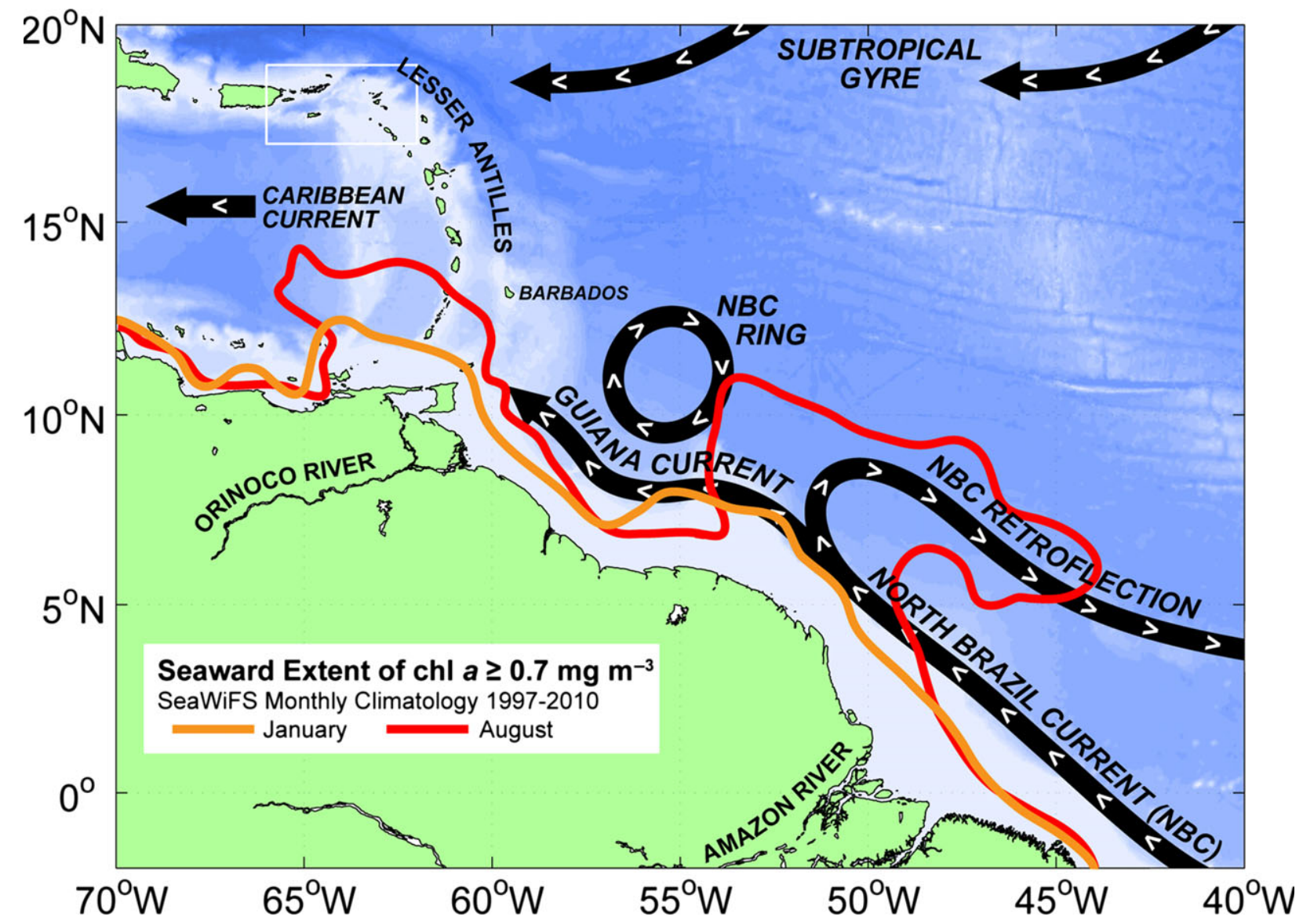

current usually reach the Caribbean Sea between about May and September. Plume waters typically enter the Caribbean south of $16^{\circ} \mathrm{N}$ and then disperse widely throughout the eastern Caribbean Sea, leading to slightly higher turbidity relative to the clearer oligotrophic waters of the central tropical Atlantic and northeastern Caribbean Sea (Müller-Karger et al., 1989).

Starting around June-July, surface waters of the NBC turn offshore (retroflect) and flow east towards Africa as the seasonal North Equatorial Countercurrent is established (Fig. 1, red line; Müller-Karger et al., 1988, 1995; Johns et al., 1990; Ffield, 2007; Salisbury et al., 2011). The NBC and the NBC retroflection shed large (>300 km diameter) anticyclonic rings (North Brazil Current Rings, NBCRs) throughout the year at an average frequency of one every $\sim 50$ 60 days (Bruce et al., 1985; Johns et al., 1990; Goni and Johns, 2001; Hu et al., 2004). These eddies frequently entrain large volumes of Amazon River water and drift northwestward along the coast of South America (Fig. 1) until they impinge on Barbados and the Lesser Antilles. The eddies and river plume either continue to the north in the Atlantic, east of these islands, or dissipate at more tropical latitudes both within the Caribbean and to the east and north (Wilson and Johns, 1997; Murphy and Hurlburt, 1999; Johns et al., 2002; Fratantoni and Richardson, 2006; Cherubin and Richardson, 2007; Ffield, 2007).

The processes of dispersal of Amazon water within the Caribbean Sea are complex and difficult to trace because the patterns of Amazon River plume dispersal vary from year to year, in both size and location (Müller-Karger et al., 1988, 1989; Müller-Karger, 1993; Hu et al., 2004; Ffield, 2005, 2007; Cherubin and Richardson, 2007; Salisbury et al., 2011). In addition, discharge from the Orinoco River enters directly into the southeastern Caribbean Sea and also affects 
the regional surface water properties (Müller-Karger et al., 1989; del Castillo et al., 1999; Odriozola et al., 2007; López et al., 2012).

To further complicate matters, remnants of the previous year's Amazon plume can mix with newlyformed Amazon River water plumes and move towards the Caribbean to intersperse with the Orinoco plume waters (Müller-Karger et al., 1988, 1989; Müller-Karger, 1993; Hu et al., 2004; Cherubin and Richardson, 2007). The combined plume typically reaches the region south of Puerto Rico by about October, or about 3-4 months after the peak seasonal rains in northeast South America (Müller-Karger et al., 1989; Corredor and Morell, 2001; Hu et al., 2004; Cherubin and Richardson, 2007).

In the western Atlantic, the brackish boluses of Amazon River water modify the ecology of the otherwise oligotrophic areas. They carry higher concentrations of phytoplankton, zooplankton and nutrients than surrounding waters (Ketchum and Ryther, 1966; Ryther et al., 1967; Hulburt and Corwin, 1969; Borstad, 1982a,b; Subramaniam et al., 2008). Further downstream, the intrusion of Amazon River water leads to seasonal shifts in the local and pelagic fisheries of Barbados and the Lesser Antilles islands, located to the west of Barbados (Fig. 1; Kelly et al., 2000). Cowen et al. (2003) demonstrated changes in vertical distribution, slower growth rates and longer larval stages in Barbados coral reef fish larvae when Amazon River water was present. They concluded that the presence of Amazon River water reduces survival and leads to lower recruitment of local coral reef fish.

Several reef fish species spawn in the northeastern Caribbean Sea. This includes commercially important snappers and groupers (Munro et al., 1973; Kadison et al., 2006). Once hatched, larvae are pelagic for several weeks before recruiting to benthic habitats (Brothers et al., 1983). Variability in the strength and location of oceanographic circulation features has been shown to define the transport patterns of fish larvae, and ultimately affect recruitment success (Shulman and Ogden, 1987; Booth and Beretta, 1994; Grothues and Cowen, 1999; Hare et al., 2001). Thus it is possible that episodic river plume events might be capable of disrupting the transport patterns and recruitment success of Caribbean reef fish larvae.

An interdisciplinary research cruise was conducted in the northeast Caribbean in April 2009 as part of a time series of shipboard observations designed to study the connection between ocean circulation and larval reef fish assemblages (Fig. 2). The oceanographic and larval fish assemblage characteristics of the anomalous Amazon River plume and its surrounding waters are examined herein in the context of satellite ocean color

Figure 2. Cruise track, sampling locations and surface drifter deployment sites for NOAA oceanographic cruise NF-09-03, conducted in April 2009.

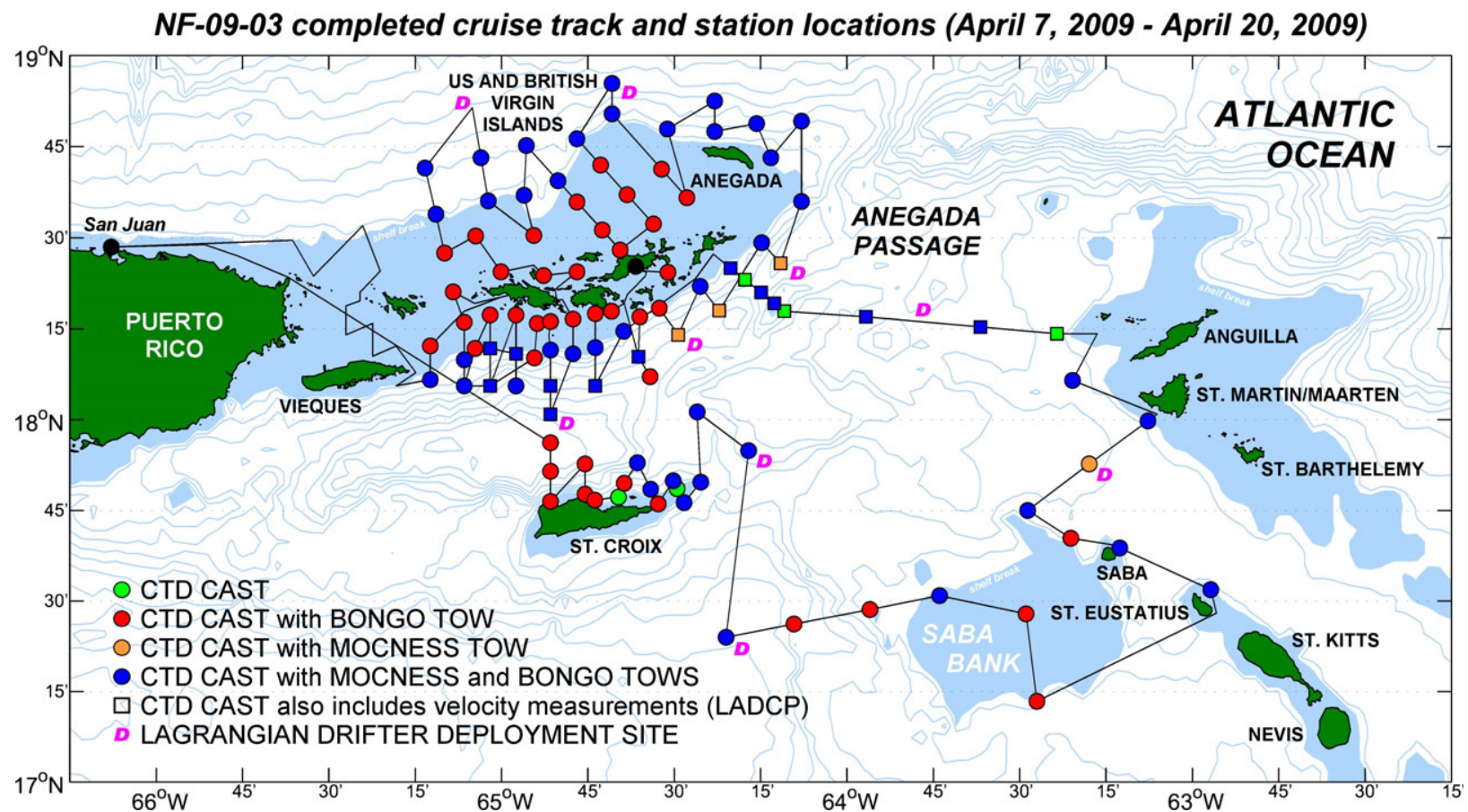

(C) 2014 John Wiley \& Sons Ltd, Fish. Oceanogr., 23:6, 472-494. 
imagery, shipboard observations including net tows, satellite-tracked near-surface drifters, and a dataassimilating numerical circulation model. From these recent observations, significant alterations in the local reef fish populations were found to be associated with the presence of the Amazon River water.

\section{MATERIALS AND METHODS}

\section{Remote sensing observations}

Satellite images of sea surface chlorophyll-a (chl-a) from the Sea-viewing Wide Field-of-View Sensor (SeaWiFS; 1997-2010) and the NASA Moderate Resolution Imaging Spectroradiometer (MODIS; 20022013) were obtained by ground stations located at the University of South Florida (USF) and from NASA's Goddard Space Flight Center (NASA GSFC). They were used to track the spring 2009 Amazon River plume in the western Atlantic Ocean and Caribbean Sea. The images were processed using NASA SeaDAS software to obtain an estimate of the pigment concentration in surface waters (chl-a plus phaeopigments; O'Reilly et al., 2000). Monthly and weekly composite images were constructed to track the large-scale features of the plume and its dispersal throughout the eastern Caribbean. To help understand the spatial patterns observed, we also examined weekly and monthly images of the European Space Agency's MEdium Resolution Imaging Spectrometer (MERIS), served by the NASA GSFC ocean color group.

Real-time SeaWiFS and MODIS data were transmitted to the ship by USF during the cruise to identify features such as fronts and gyres, helping to guide field sampling and drifter deployment locations. Monthly SeaWiFS and MODIS chl-a data obtained from NASA's Giovanni online data system (Acker and Leptoukh, 2007) were also used in post-processing as a convenient tool to examine the spatial and temporal variability of the plume relative to long-term chl-a time series for the study area.

\section{Mercator Océan global ocean analysis}

Regional sea surface height ( $\mathrm{SSH})$, near-surface $(1 \mathrm{~m})$ salinity and ocean current fields were examined for the period January to June 2009 using the operational, data-assimilating global Mercator Océan numerical simulations (Timmermann et al., 2004; Barnier et al., 2006; Drévillon et al., 2008; Madec, 2008). The model has a nominal horizontal resolution of $1 / 4^{\circ}$ at the equator and finer resolution with increasing latitude. It has 50 vertical levels, with 11 levels in the top $15 \mathrm{~m}$. Data are assimilated using a reduced-order Kalman filter (Pham et al., 1998) adapted for eddy-resolving global ocean model configurations (Tranchant et al., 2008). Assimilated data include remotely-sensed SSH anomalies and mean dynamic topography, sea surface temperature (SST) and in situ temperature and salinity profiles. The model results were used to synthesize the ambient physical oceanography of the region, and provide a better means of testing hypotheses relating to the origin and dispersal of the Amazon River plume than the data alone would have provided.

\section{In situ oceanographic observations}

A multidisciplinary research cruise involving fisheries biologists and physical oceanographers was conducted in the northeastern Caribbean Sea during April 7-20, 2009, aboard the NOAA Ship Nancy Foster (NOAA cruise NF-09-03). The cruise track, station locations and sampling plan are shown in Fig. 2.

Ten Standard Velocity Profiler (SVP) Lagrangian surface drifters were deployed to help understand circulation features identified in the ocean color satellite imagery. The drifters were drogued to $15 \mathrm{~m}$ and tracked via the Argos satellite (Lumpkin and Pazos, 2007). These drifting buoys were used to follow the synoptic regional surface flow and to assess its connectivity with larger-scale circulation patterns.

Continuous along-track SST, surface salinity (SSS) and fluorescence measurements were collected using the ship's flow-through SBE-21 thermosalinograph (TSG) system, and Turner 10 (Leg 1, April 7-13) and Seapoint (Leg 2, April 15-20) fluorometers. The data were logged at 10-s intervals and referenced with Global Positioning System (GPS) data. The SSS data were used in our analyses to distinguish between three surface water types, namely Atlantic, Caribbean and Amazon River plume, in near-real-time, in combination with the satellite imagery and water color observed from the deck of the ship.

Vertical hydrographic profiles were collected using a Sea-Bird 911plus CTD (conductivity-temperaturedepth) system equipped with dual conductivity, temperature and dissolved oxygen (SBE 43) sensors, and a single chl-a fluorescence (Wetlabs ECO-AFL) probe. Most of the CTD stations were occupied to a depth of $300 \mathrm{~m}$ or to the seafloor, whichever was shallower. Full water column profiles were collected across Anegada Passage to $\sim 1800 \mathrm{~m}$ depth. Here we focus on the nearsurface $(<100 \mathrm{~m})$ observations collected during the cruise, which are most relevant to describing the characteristics of the river plume water and its effect on the larval fish distributions.

Water samples were collected using 10-L Niskin bottles mounted on the CTD package. Samples were collected at the maximum cast depth, the depth of 
maximum fluorescence, and from just below the surface. Water samples were filtered for in situ chl-a concentration as described by Kelble et al. (2005). Due to the sparse vertical bottle sampling, the chl-a fluorescence profiles were not calibrated to the sampled chl- $a$ and will be shown below as relative fluorescence profiles. There was a robust linear correlation between the surface chl-a samples and the surface fluorometer data $\left(R^{2}=0.77\right)$. The fluorometer values and chl-a sample concentrations were nearly equal at the low end of their range, but at the high end of the range (i.e., in the plume) the measured chl-a concentrations were approximately a factor of nine higher than the fluorescence values. The dissolved oxygen (DO) content of the bottle samples was estimated using the standard Winkler titration method and used to check the calibration of the CTD DO sensors. Objectivelyinterpolated contour maps of SST and SSS (from the continuous TSG system), and oxygen and chl-a (from the discrete station sample data) were produced using Golden Software, Inc. (Golden, CO, USA)'s SURFER 'kriging' objective interpolation software. Additional details on shipboard instrumentation, methods and data accuracy are available in the NF09-03 cruise report (Smith, 2009).

\section{Larval fish and plankton sampling}

Larval fish collections were conducted using a $0.9-\mathrm{m}^{2}$ bongo net with a mesh size of $0.505 \mathrm{~mm}$. The bongo net sampled obliquely from the surface to $10 \mathrm{~m}$ depth for $10 \mathrm{~min}$, at a towing speed of 1.5-2.0 kts. Volumes of seawater filtered by the net were calculated using a General Oceanics mechanical flow meter attached to the net mouth. Settled total phyto- and zooplankton volumes (in units of $\mathrm{mL} \mathrm{m}^{-3}$ of seawater sampled) were measured at each station. Depth-stratified plankton sampling was conducted using a Multiple Opening/Closing Net and Environmental Sampling System (MOCNESS) at deeper (offshore and shelf break) sampling stations. The MOCNESS sampled four discrete strata: 0-25 m (Net 5), 25-50 m (Net 4), 50$75 \mathrm{~m}$ (Net 3) and 75-100 m (Net 2). A mean of $332.8 \mathrm{~m}^{3}$ of water was filtered by each net. All nets were constructed with a $0.333-\mathrm{mm}$ mesh and a $1-\mathrm{m}^{2}$ mouth opening. Not all net sampling gear was deployed at all stations (Fig. 2).

Plankton samples were fixed in 95\% Ethanol at sea which was refreshed $24 \mathrm{~h}$ later to adequately preserve samples. Fish larvae were removed from all plankton samples, and identified to the family level using techniques described in Richards (2005). Larvae from three reef-associated families were identified to the genus level: Labridae $(n=1096)$, Serranidae $(n=465)$ and Scaridae $(n=2211)$. The standard length of 1038 of these larvae was measured to the nearest $0.1 \mathrm{~mm}$, using an eyepiece micrometer fitted to a dissecting microscope. The mean abundance and length of larvae from the two most abundant genera from each of these three families were then compared for different sampling depths. The sampling depths of the two plankton sampling gears were compared by taking the median depth covered by each depth bin: $5 \mathrm{~m}$ for the bongo net, and 87.5, 62.5, 37.5 and $12.5 \mathrm{~m}$ for each of the four MOCNESS depth strata.

Statistical differences in larval fish assemblages among the three water types identified using the along-track SSS data were evaluated using a non-parametric, multivariate permutational analysis of variance (PERMANOVA; Anderson, 2001) within each net type (bongo, and MOCNESS Nets 2-5). There was only one plume sample available for the two deepest MOCNESS nets, and so Monte Carlo sampling was used to derive $P$-values for pairwise comparisons involving these samples. The similarity percentage routine SIMPER was then used to identify the families which were most responsible for distinguishing assemblages among the different water masses. This analysis considers the mean abundance and standard deviation of different taxa among sample groups, with scores for each taxa determined by considering the contribution to overall dissimilarity among groups (Clarke, 1993). Samples from bongo nets and the two shallowest MOCNESS nets (Nets 4-5) were combined within stations for this analysis. All multivariate statistical analyses were completed using PRIMER-E software (Clarke and Gorley, 2006).

Results from the 2009 cruise were compared with larval fish abundances for two selected families (Myctophidae and Scaridae) from similar cruises previously completed in the region in 2007 and 2008, between March and May. These samples were collected and processed in the same manner as for 2009.

\section{RESULTS}

\section{Origin and dispersal of the plume}

A sequence of monthly MODIS ocean color composites illustrates the dispersal of the Amazon and Orinoco River plumes between January and September 2009 (Fig. 3). The January image shows a coastal river plume with a relatively high pigment concentration entering the Caribbean south of $12^{\circ} \mathrm{N}$. This pattern is typical for this time of the year (Fig. 1) and shows the impact of the mixture of Amazon and Orinoco River plume waters on the coasts of Venezuela, Trinidad and Tobago, and the southernmost Lesser Antilles islands 
Figure 3. Monthly chlorophyll-a (chl-a) concentration (in $\mathrm{mg} \mathrm{m}^{-3}$ ) composite images derived from the MODIS Terra satellite sensor for January through to September 2009, produced by the University of South Florida (USF) Institute for Marine Remote Sensing (IMaRS). All map coordinates are $0-22^{\circ} \mathrm{N}, 75-45^{\circ} \mathrm{W}$, and the chl-a color scale ranges from $<0.10$ (dark purple tones) to $7.0 \mathrm{mg} \mathrm{m}^{-3}$ (red tones).
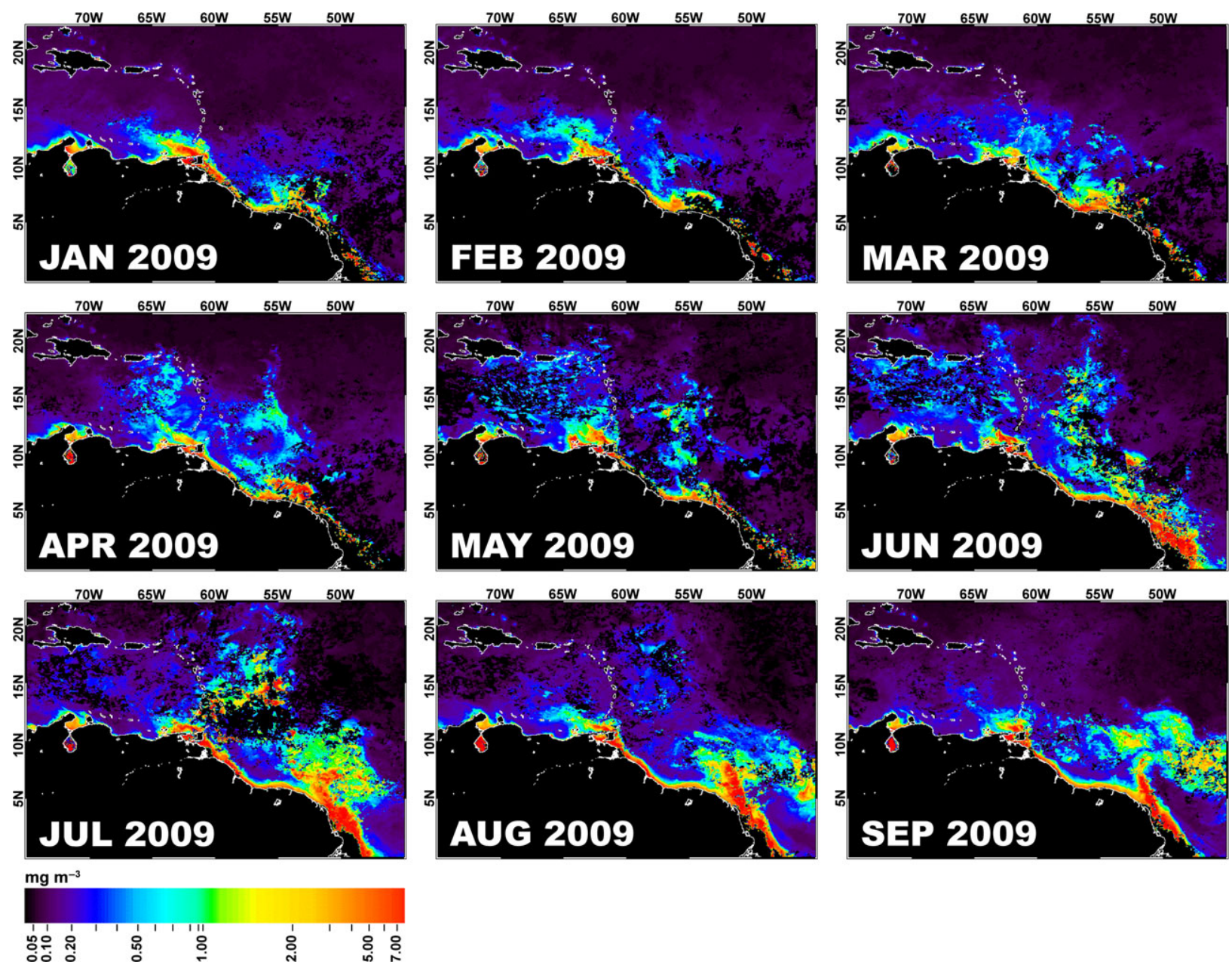

around Grenada. In February, a second plume of slightly lower pigment concentration extended north along about $58^{\circ} \mathrm{W}$ to $14^{\circ} \mathrm{N}$, east of Barbados. Satellite altimeter data (not shown) confirmed that this second plume was associated with a NBCR that formed around October 2008 from the NBC retroflection. This ring was also present in a numerical simulation of the Mercator Océan global ocean operational analysis (see below). In March 2009, as the NBCR impinged on the Lesser Antilles, chl-a concentrations increased around the islands up to $\sim 15^{\circ} \mathrm{N}$, including west of the islands inside the eastern Caribbean Sea. By April, the entire northeastern Caribbean east of $67^{\circ} \mathrm{W}$ and north to about $19^{\circ} \mathrm{N}$ was covered with the plume.

Examination of the monthly mean satellite-derived ocean color products (Fig. 3) could lead to the conclusion that the high chl-a features observed immediately to the west of the Lesser Antilles and extending from Venezuela to the Virgin Islands is part of the Orinoco River plume. However, careful examination of daily and weekly mean chl-a images from SeaWiFS, MODIS and MERIS (for example, those in Fig. 4) helps piece together a complex puzzle that shows that the high chl-a water seen north of about $14^{\circ} \mathrm{N}$ immediately west of the Antilles is contained in boluses of Amazon water that moved across the island chain and started to move rapidly toward the islands in the vicinity of the Virgin Islands to the north.

The 'green water' began to envelope the Virgin Islands starting the first week of April, 2009. The northern edge of the plume spread approximately four degrees in both latitude and in longitude from March 
Figure 4. Weekly chlorophyll-a (chl-a) concentration (in $\mathrm{mg} \mathrm{m}^{-3}$, same color scale as in Fig. 3) composite images derived from the MODIS Terra satellite sensor for 2, 9, 16 and 23 April, 2009, produced by the USF IMaRS. All map coordinates are 8-21 ${ }^{\circ} \mathrm{N}$, $77-58^{\circ} \mathrm{W}$. The white rectangle shows the cruise study area, $17-19^{\circ} \mathrm{N}, 66-62^{\circ} \mathrm{W}$.
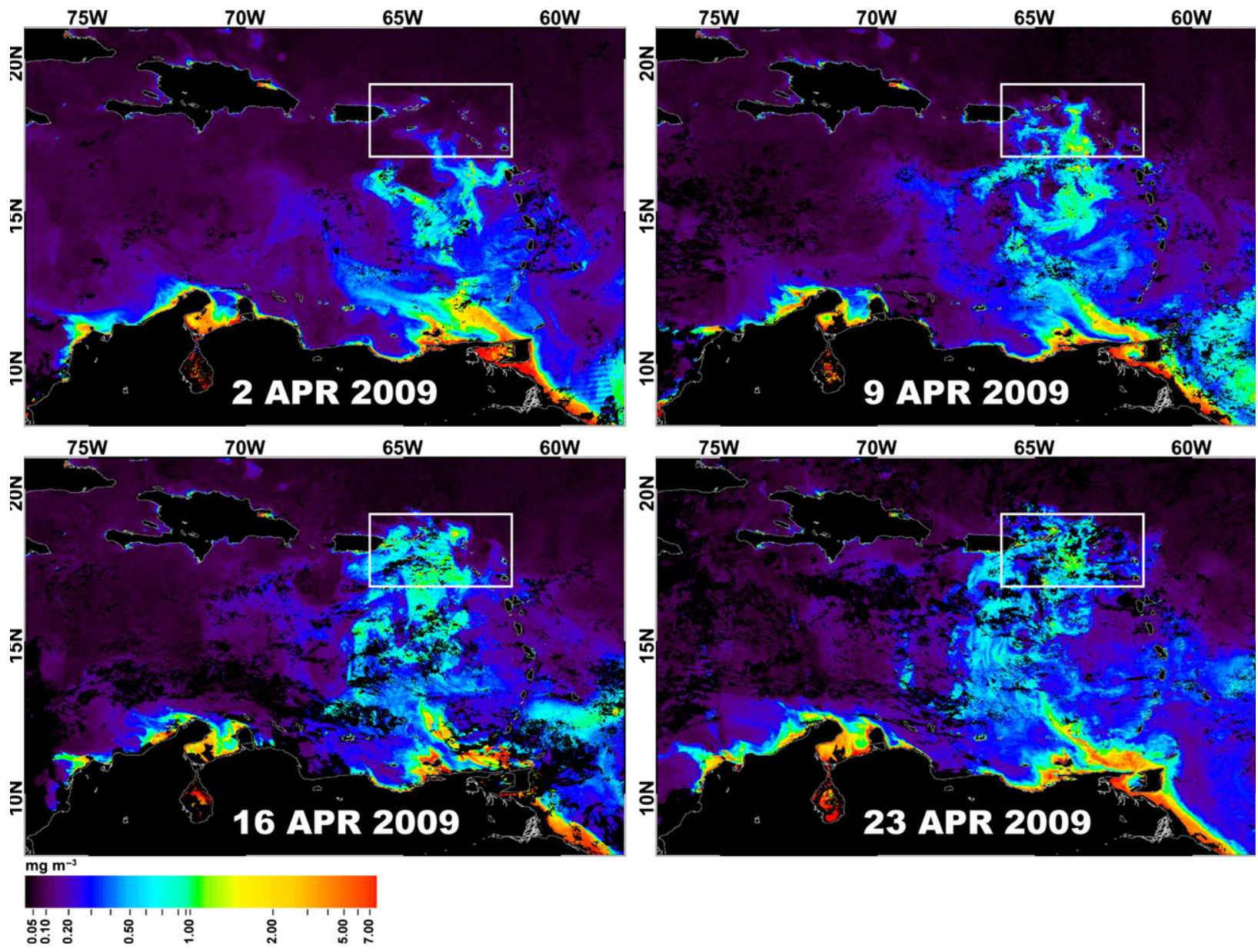

to April, implying an average advection rate of about $17 \mathrm{~cm} \mathrm{~s}^{-1}$. By May, the plume had spread westward to $72^{\circ} \mathrm{W}$ and northward to $20^{\circ} \mathrm{N}$ into the open Atlantic, north of the Virgin Islands. Chl-a concentrations between 0.3 and $0.5 \mathrm{mg} \mathrm{m}^{-3}$ and higher remained in the vicinity of the Virgin Islands through June 2009, as the bulk of the plume dissipated farther into the Caribbean Sea to the west, and northwest into the western subtropical Atlantic.

Beginning in April 2009, yet another mass of Amazon River water was observed to the east of the central Caribbean island arc. This water was associated with a new NBCR. This second NBCR of 2009 spread Amazon River water to the north and east of the Lesser Antilles during May through to July, into the subtropical Atlantic. Finally, by August and September, the NBCRs had largely dissipated. By this time, the seasonal NBC retroflection (Fig. 1) had developed.
For a closer look at the high chl-a plume during the NOAA cruise, a sequence of 4 weekly ocean color composite images was generated for April 2009 (Fig. 4). The images show the extent and complex spatial structure of the plume. The week before the cruise (weekly composite beginning on April 2), the leading edge of the plume was just beginning to enter the southern part of the study area (white rectangle indicating $17-19^{\circ} \mathrm{N}, 66-62^{\circ} \mathrm{W}$; see also Fig. 2). By April 9, during the first week of the cruise, some filaments of high chl-a extended north and west of the Virgin Islands and Anegada Passage. By April 16, during the second half of the cruise, the plume extended well north of the Virgin Islands and Anegada Passage and west along the southern coast of Puerto Rico. Finally, by the week beginning on April 23, after the cruise was completed, the plume began to slowly dissipate. 
Figure 5. Monthly maps of sea surface height (in $\mathrm{cm}$ ) from the Mercator Océan analysis product in the Caribbean. Black lines are used for the $-20,-10,-5,5,10$ and $20 \mathrm{~cm}$ contours. Blue shading shows the lower (negative anomaly) areas of sea surface height. Thin vectors indicate the direction of near-surface $\left(1 \mathrm{~m}\right.$ depth) surface currents with speeds between 25 and $50 \mathrm{~cm} \mathrm{~s}{ }^{-1}$, and thick vectors indicate currents with speeds in excess of $50 \mathrm{~cm} \mathrm{~s}^{-1}$. The black box indicates the $17-19^{\circ} \mathrm{N}, 66-62^{\circ} \mathrm{W}$ cruise domain.
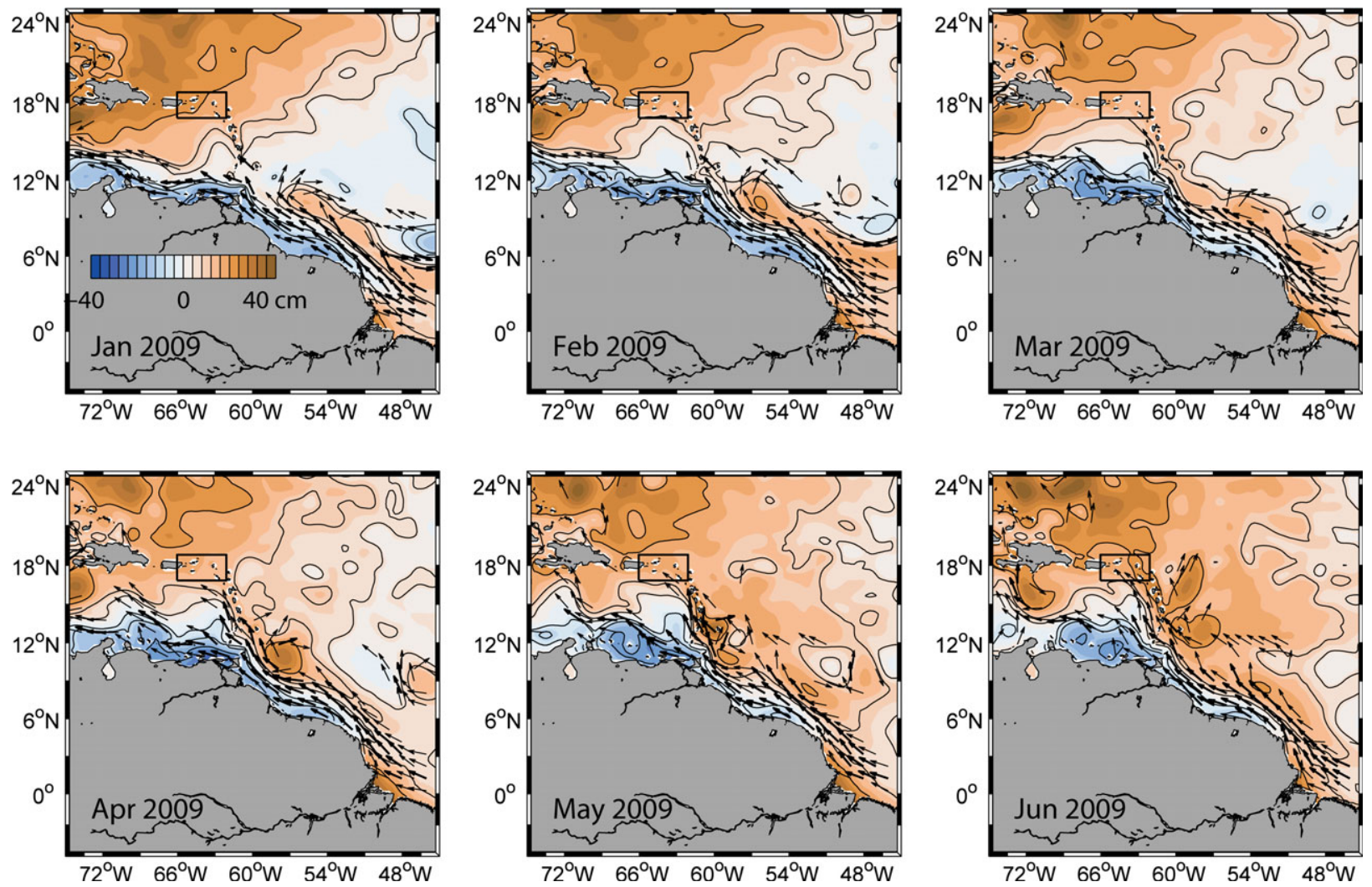

Mercator Océan SSH and near-surface salinity and velocity fields

The Mercator Océan global ocean operational analysis was used to study the mechanics of regional $\mathrm{SSH}$, near-surface $(1 \mathrm{~m})$ salinity and flow fields during the first 6 months of 2009. Maps of simulated monthly $\mathrm{SSH}$ and near-surface $(1 \mathrm{~m})$ currents are shown in Fig. 5. During October 2008, the North Brazil Current retroflection shed a ring (not shown). By February 2009, this NBCR, having a high SSH (orange tones), was located to the east of the southeastern Caribbean and Barbados, causing northward geostrophic flow from about $10^{\circ} \mathrm{N}, 62^{\circ} \mathrm{W}$ to at least $14^{\circ} \mathrm{N}$ along the Lesser Antilles. A cyclonic circulation (i.e., a relative depression in SSH, blue tones) developed during this time on the Caribbean side of the islands, immediately west of the central Lesser Antilles. This suggests that upwelling may have occurred in this area, bringing nutrients closer to the surface and intensifying the plankton bloom observed in satellite images on the
Caribbean side of the Lesser Antilles. The strengthening, positive west-to-east gradient in SSH across the island arc from the low SSH values just inside the Caribbean to the high SSH values offshore, most notable from March to June 2009, contributed to the intensity of the northward jet along the islands (with current speeds $>25 \mathrm{~cm} \mathrm{~s}^{-1}$ ) and the rapid northward spread of the Amazon plume waters on the Caribbean side of the islands during this time.

Monthly mean near-surface $(1 \mathrm{~m})$ salinity maps from the Mercator Océan analysis product (Fig. 6) show fresh water (dark blue tones), advected with the NBCR, approaching the Lesser Antilles during January and February 2009 and entering the eastern Caribbean Sea in March 2009, following the strong northward jet along the arc of the Caribbean islands, and remaining in the northeastern Caribbean through to June 2009. These results, depicting the northward spreading of the Amazon River water, are in good agreement with the MODIS ocean color images described in the previous section. 
Figure 6. Monthly maps of near-surface salinity (at $1 \mathrm{~m}$ depth) from the Mercator Océan analysis product in the Caribbean. Black lines are used for the 35, 36, and 37 salinity contours. Blue shading shows the relatively fresher water. The near-surface ( $1 \mathrm{~m}$ depth) current vectors and the cruise domain box are the same as in Fig. 5.
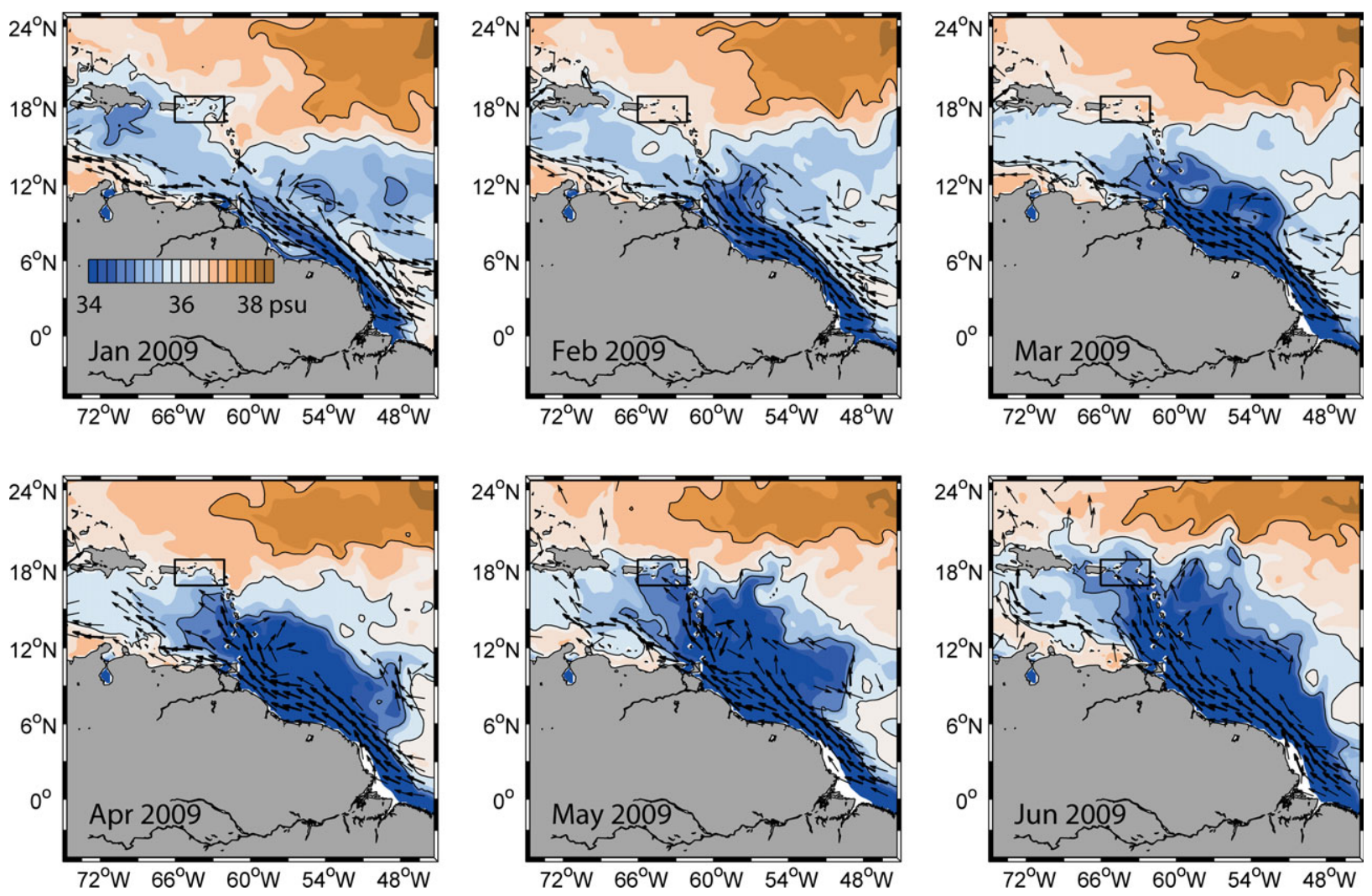

Analysis of Mercator Océan analysis products (not shown) for January through to June of 2007 through 2010 confirms that in 2009 the Amazon River water entered the Caribbean several months earlier than during the two previous years, with larger negative (fresh) salinity anomalies in boreal spring/summer observed in the northeastern Caribbean than in previous years. In 2010, a similar extreme event followed the 2009 plume event in the Mercator Océan global ocean operational analysis; this will be discussed later in the context of historical measurements in the region.

\section{Hydrographic observations}

Maps of in situ SSS, SST, surface dissolved oxygen and surface chl-a are shown in Fig. 7(a-d). Based on SSS alone, three water types were identified: plume waters are defined as those stations with SSS < 35.9 (dark blue to purple tones), Caribbean waters as SSS from 35.9 to 36.6 (turquoise, green and yellow tones) and North Atlantic water as SSS $>36.6$ (orange and red tones). By these definitions, North Atlantic surface water was located to the north of Anegada, Amazon
River plume water was located in the south-central portion of the region, and Caribbean surface water was located on the northwest and east sides of the study area. The property maps confirm a close association within the plume between lower salinity $(35.76 \pm 0.05$ PSU), and higher surface chl-a $\left(1.26 \pm 0.21 \mathrm{mg} \mathrm{m}^{-3}\right)$, higher SST $(26.67 \pm$ $\left.0.14^{\circ} \mathrm{C}\right)$, and higher dissolved oxygen (4.90 \pm $\left.0.06 \mathrm{~mL} \mathrm{~L}^{-1}\right)$, as listed in Table 1 . The plume was nearly $1^{\circ} \mathrm{C}$ warmer, $1 \mathrm{PSU}$ fresher, $0.3 \mathrm{~mL} \mathrm{~L}^{-1}$ higher in dissolved oxygen and $1.2 \mathrm{mg} \mathrm{m}^{-3}$ higher in chl-a than nearby Atlantic Ocean waters, with adjacent Caribbean surface waters falling between the other two water types (Table 1).

The chl-a values previously shown in the weekly composite MODIS images for the weeks beginning April 9 and April 16, 2009, are in the 1.0-2.0 $\mathrm{mg} \mathrm{m}^{-3}$ range within the plume (green and yellow tones, Fig. 4). The satellite-derived values were expected to be higher than the chl-a concentrations sampled from the ship due to the likely presence of colored dissolved organic matter, or CDOM, as has been observed previously in the Orinoco River plume (Müller-Karger 
Figure 7. Maps of in situ sea surface salinity (a), sea surface temperature (b), dissolved oxygen (c) and chlorophyll-a (chl-a) (d) from the 7-20 April 2009 research cruise. The salinity and temperature fields are from the thermosalinograph (TSG) system, and the dissolved oxygen and chl- $a$ are from the water samples collected at each station. The 35.9 and 36.6 salinity contours, which delineate the plume boundaries and the stations used for the statistical groupings in Table 1, are superimposed on all of the panels in white. Hydrographic stations no. 83 (in the plume) and no. 47 (in the Atlantic), used in the vertical profiles of Fig. 8, are labeled on the sea surface salinity map.

(a)

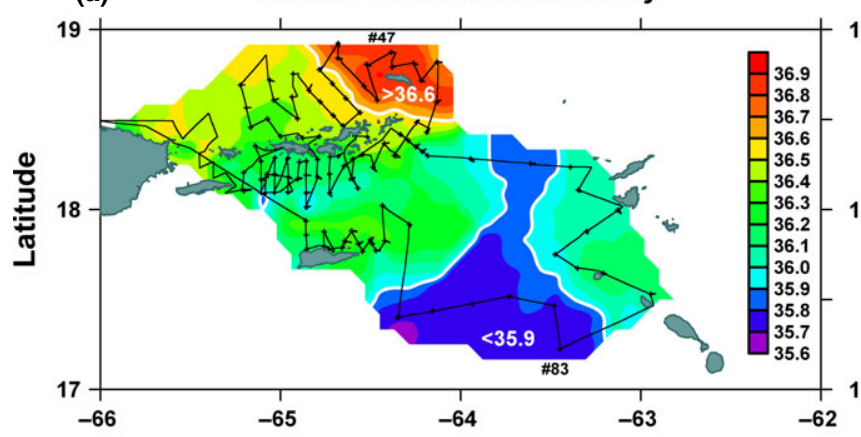

(c)

NF0903 Sea Surface Oxygen $\left(\mathrm{ml} \mathrm{L}^{-1}\right)$

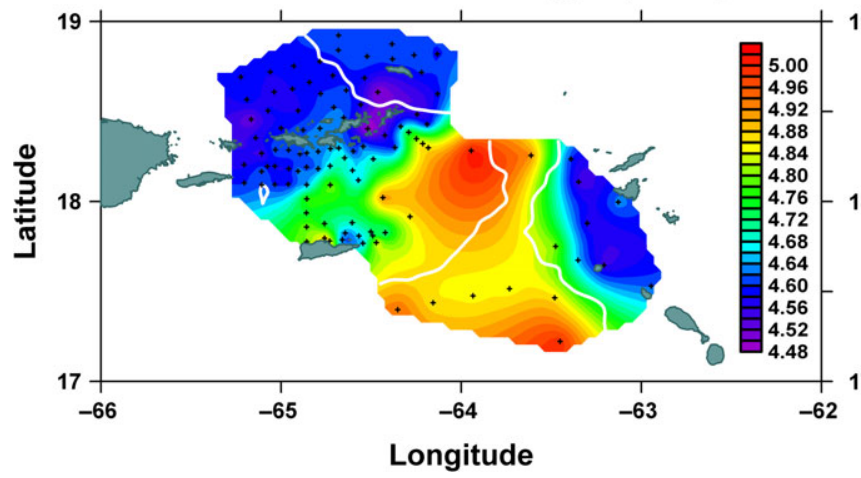

(b) NF0903 Sea Surface Temperature (deg C)

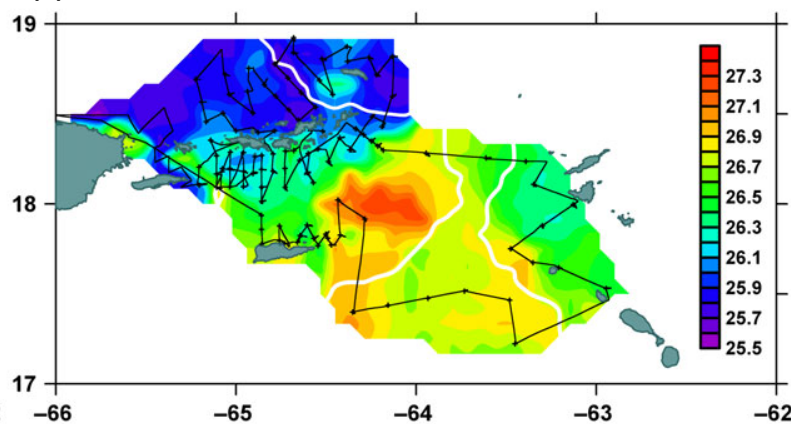

(d) NF0903 Sea Surface Chlorophyll a $\left(\mathrm{mg} \mathrm{m}^{-3}\right)$

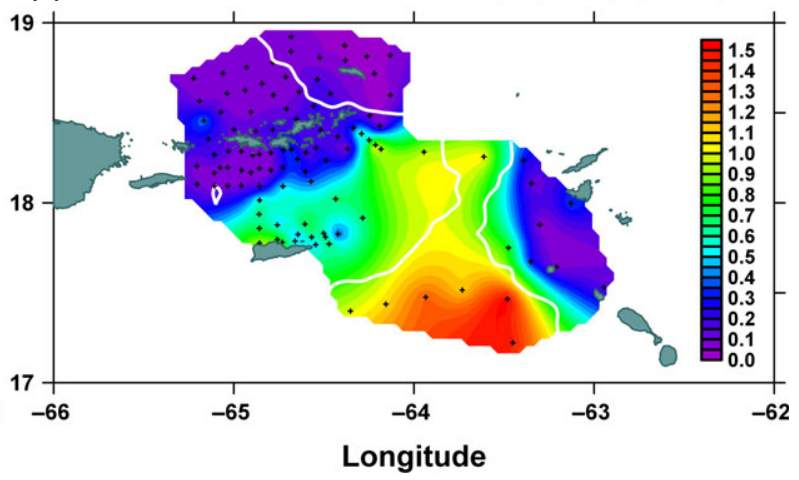

Table 1. Mean and standard deviation of sea surface temperature (SST), salinity (SSS), dissolved oxygen $\left(\mathrm{O}_{2}\right)$, and chlorophyll-a (chl-a) for the Atlantic, Caribbean and plume water types, and cruise averages for these parameters. The three water types were defined by SSS, where Atlantic waters were defined as SSS $>36.6$, Caribbean waters as $35.9<$ SSS $<36.6$, and plume waters as SSS < 35.9 (Fig. 7).

\begin{tabular}{lccccc}
\hline Water type & No. stations & SST $\left({ }^{\circ} \mathrm{C}\right)$ & SSS $(\mathrm{psu})$ & $\mathrm{O}_{2}\left(\mathrm{~mL} \mathrm{~L}^{-1}\right)$ & $\mathrm{Chl}^{-a}\left(\mathrm{mg} \mathrm{m}{ }^{-3}\right)$ \\
\hline Atlantic & 12 & $25.91 \pm 0.19$ & $36.79 \pm 0.09$ & $4.60 \pm 0.03$ & $0.07 \pm 0.04$ \\
Caribbean & 86 & $26.26 \pm 0.32$ & $36.26 \pm 0.17$ & $4.65 \pm 0.10$ & $0.31 \pm 0.28$ \\
Plume & 7 & $26.77 \pm 0.14$ & $35.76 \pm 0.05$ & $4.90 \pm 0.06$ & $1.26 \pm 0.21$ \\
Average & 105 & $26.25 \pm 0.35$ & $36.29 \pm 0.27$ & $4.66 \pm 0.12$ & $0.34 \pm 0.36$ \\
\hline
\end{tabular}

et al., 1989; del Castillo et al., 1999; Salisbury et al., 2011; López et al., 2012). However, in this case the satellite-derived estimates of chl- $a$ in the plume were in good qualitative agreement with the chl-a sample observations from the cruise (which showed a mean of $1.26 \pm 0.21 \mathrm{mg} \mathrm{m}^{-3}$ for the seven plume stations, Table 1).

Selected CTD profiles of temperature, salinity, fluorometer voltage and dissolved oxygen (Fig. 8) show that the low-salinity, high-chlorophyll plume was 20$30 \mathrm{~m}$ thick. In contrast, profiles in North Atlantic water showed waters well mixed to $>100 \mathrm{~m}$. The transition from salinity $\sim 35.7$ at $20 \mathrm{~m}$ to $\sim 36.9$ at $75 \mathrm{~m}$ and below (i.e., close to the Atlantic profile) in the plume profile shows that mixing between the buoyant plume and the underlying waters was limited along the $>2200 \mathrm{~km}$ transit from the Amazon River Delta to the northeastern Caribbean. The plume waters were 
Figure 8. Vertical profiles of temperature and salinity (a, left panel), and chlorophyll-a (chl-a) and dissolved oxygen (b, right panel) for representative stations (see Fig. 7) located in the plume (station no. 83, solid lines), and in North Atlantic water (station no. 47, dashed lines). Temperature is red, salinity is blue, chl a is green, and dissolved oxygen is purple. Vertical profiles of the Caribbean water type fall in general between these two types (not shown).

(a)

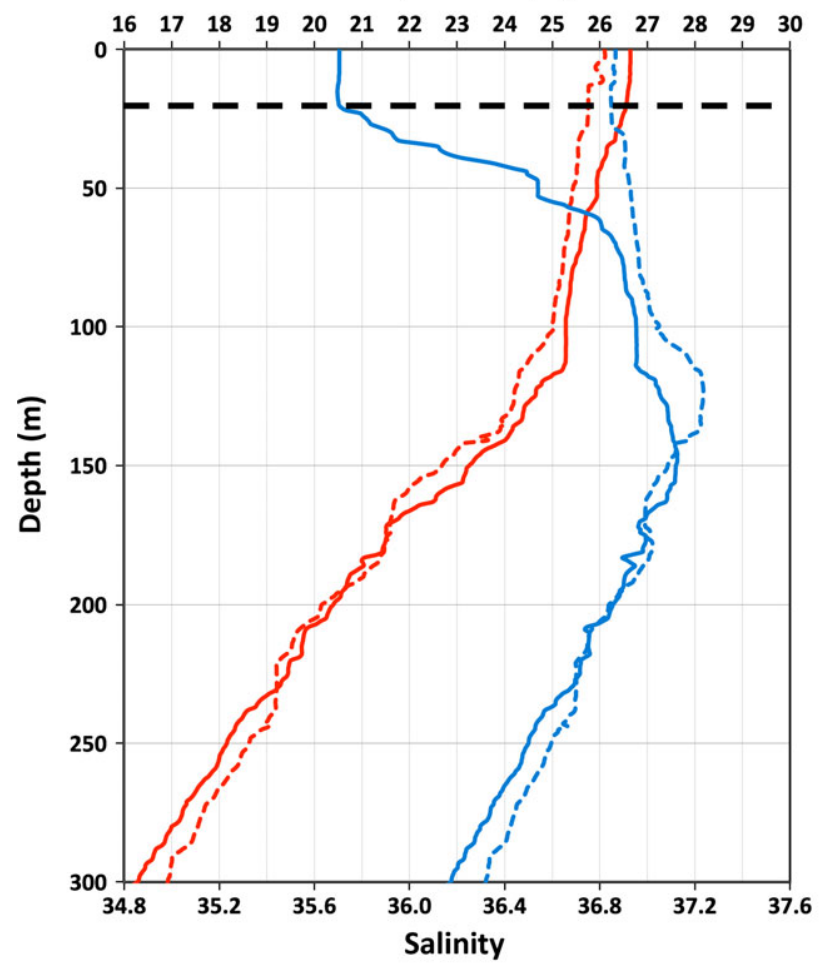

(b) chl- $a$ fluorometer voltage (VDC)

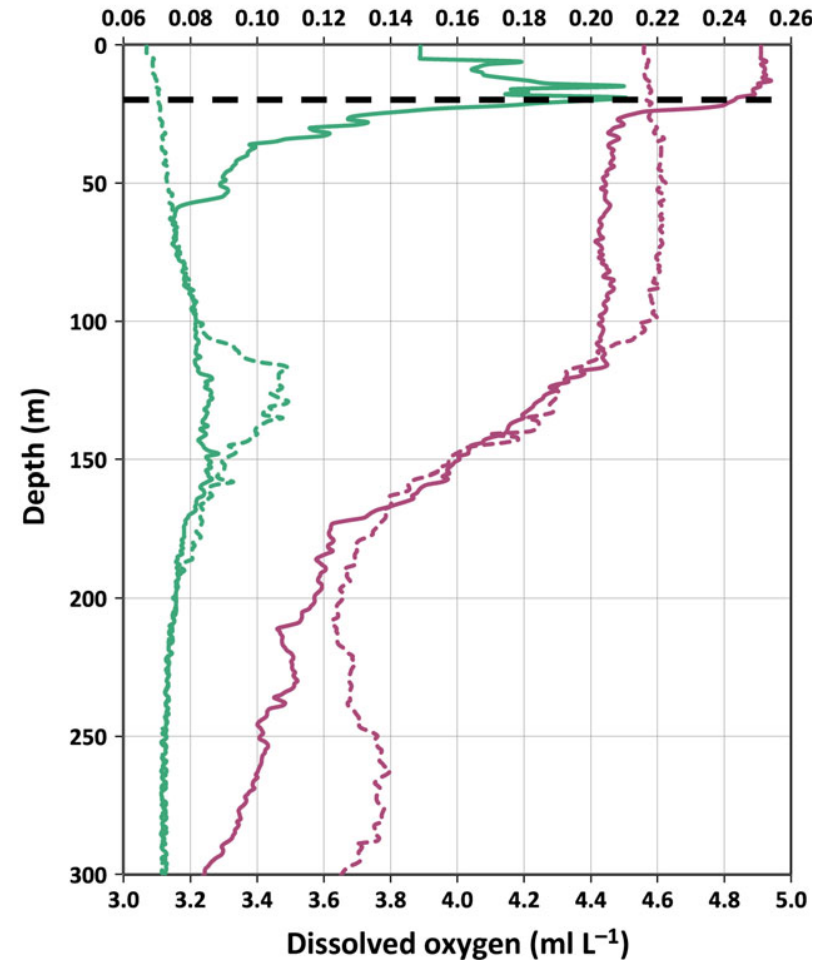

warmer than the Atlantic waters throughout the water column to about $175 \mathrm{~m}$. The dissolved oxygen profiles show a higher concentration in the plume in the upper $20 \mathrm{~m}$, but lower values just beneath the plume from 20 to $115 \mathrm{~m}$ than the Atlantic station. The relative chl-a fluorescence profiles show that although the highest values are in the upper $20-30 \mathrm{~m}$, there is also relatively high fluorescence down to $\sim 60 \mathrm{~m}$ depth within the plume water, and lower fluorescence between 100 and $190 \mathrm{~m}$.

Synoptic circulation from near-surface drifter observations

Satellite-tracked near-surface drifters deployed during the cruise were used to trace the regional ocean currents. The trajectories of the 10 drifters are shown in Fig. 9. Three drifters (dark green, yellow and turquoise) were deployed north of the Virgin Islands on 11-12 April 2009. They all traveled northwestward at $\sim 19 \mathrm{~cm} \mathrm{~s}^{-1}$ and were located north of Puerto Rico by 19-21 April 2009. Their trajectories are consistent with the mean estimated westward flow of the North Atlantic subtropical gyre (Fig. 1), with a superimposed northward Ekman drift driven by the trade winds (c.f. Gordon, 1967).

The drifters that were deployed south and east of the Virgin Islands reveal some details of the direction of dispersal of the Amazon River plume during the cruise. The easternmost drifter, deployed on April 17 between Saba Island and St. Martin (purple), traveled north at $\sim 11 \mathrm{~cm} \mathrm{~s}^{-1}$ and drifted out of the Caribbean through Anegada Passage before turning to the west north of the Virgin Islands. This trajectory was unexpected, as previous observations have documented a mean southwestward surface inflow through the Anegada Passage from the Atlantic into the Caribbean (Johns et al., 1999).

Several drifters deployed southwest of the Anegada Passage (gray, blue and black) drifted to the west just south of the Virgin Islands at $\sim 15 \mathrm{~cm} \mathrm{~s}^{-1}$. Joined by another drifter (pink) which later grounded in the islands, they turned northward, passed just west of the Virgin Islands, and continued drifting to the northwest into the Atlantic. A drifter deployed east of St. Croix (orange) traced a small cyclonic eddy before traveling westward at $\sim 26 \mathrm{~cm} \mathrm{~s}^{-1}$ just south of Puerto Rico. 
Figure 9. Satellite-tracked surface drifter trajectories for the period 10 April 2009 to 21 May 2009. Drifters were deployed during cruise NF-09-03 of NOAA Ship Nancy Foster. Deployment locations are indicated by circles (also shown in Fig. 2), daily locations by dots, and final locations if drifters became grounded before exiting the study area are shown as stars. Note that this map depicts a somewhat larger geographical area than the study area shown in Figs 1, 2, and 4.

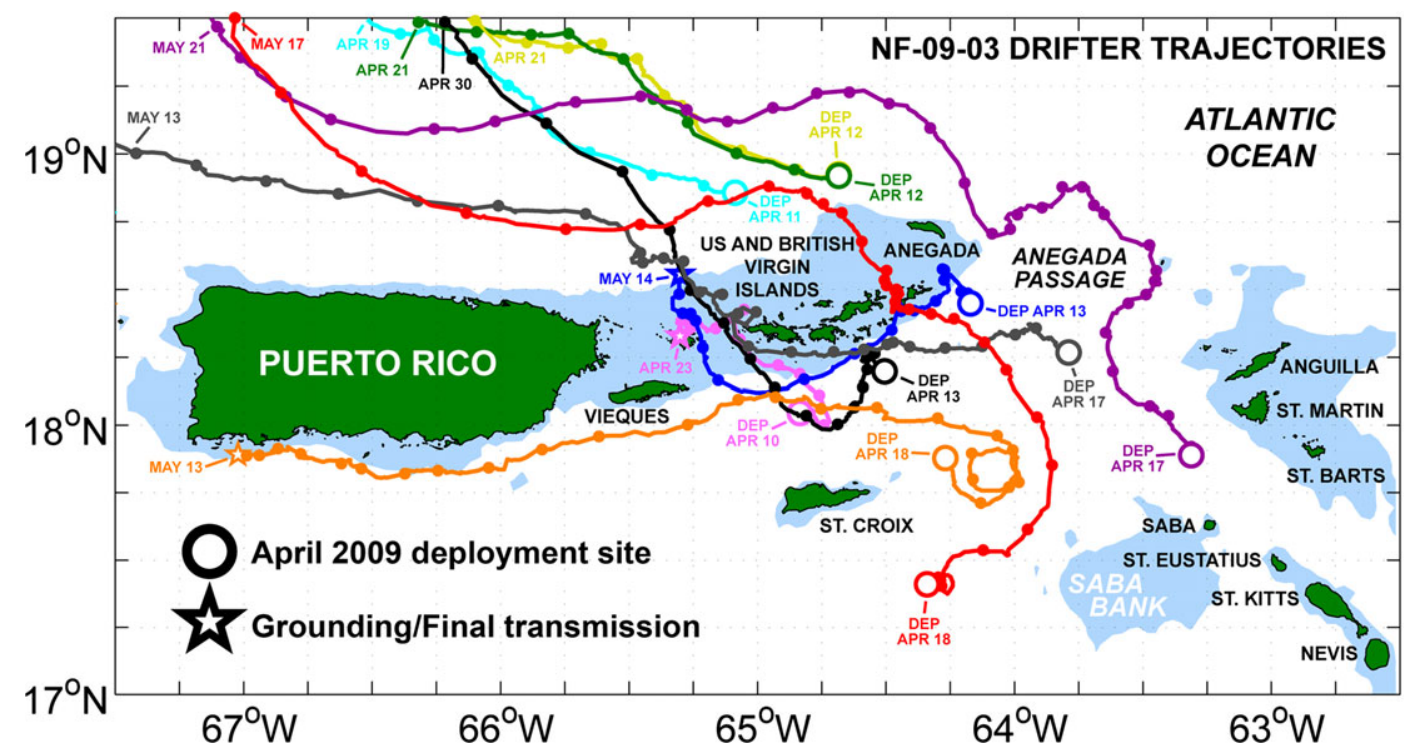

Finally, a drifter deployed southeast of St. Croix (red) moved cyclonically and then drifted to the northnorthwest at $\sim 20 \mathrm{~cm} \mathrm{~s}^{-1}$, passing between Virgin Gorda and Tortola over shallow banks before finally turning westward north of Puerto Rico within the subtropical gyre (Fig. 9).

The drifter trajectories confirm the north- and westward motion of surface waters in the northeastern Caribbean Sea during April and May 2009 at speeds of $11-26 \mathrm{~cm} \mathrm{~s}^{-1}$, in good qualitative agreement with the direction of dispersion and the advection rate of $17 \mathrm{~cm} \mathrm{~s}^{-1}$ for the plume waters estimated from the

Figure 10. Larval concentrations (in no. per $\mathrm{m}^{3}$ ) of larvae sampled in the upper $50 \mathrm{~m}$ of the water column during the April 2009 cruise, from the four fish families Myctophidae (lanternfish), Nomeidae (driftfish), Scaridae (parrotfish) and Clupeidae (herrings and menhaden). Note that the concentration scale (size of filled circles) is a factor of 10 higher for the Myctophidae and Clupeidae families than for the other two families.
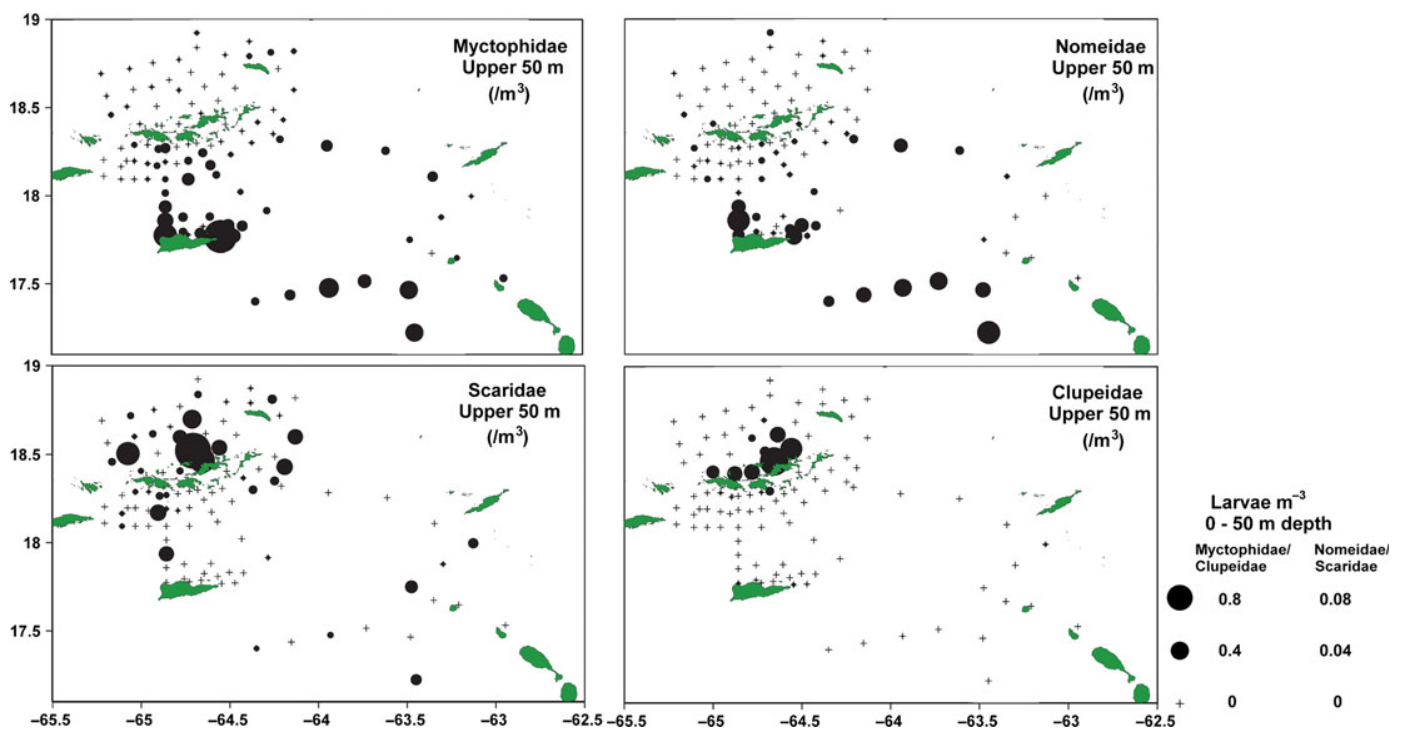

(C) 2014 John Wiley \& Sons Ltd, Fish. Oceanogr., 23:6, 472-494. 
Table 2. Twenty most abundant fish families across all plankton samples, and percentage contribution to the complete assemblage. Larvae from the families Labridae, Scaridae and Serranidae were further identified to genus level where possible.

\begin{tabular}{|c|c|c|c|}
\hline Family & Genus & $\begin{array}{c}\% \\
\text { contribution }\end{array}$ & $\begin{array}{l}\text { Total } \\
\text { larvae }\end{array}$ \\
\hline Myctophidae & & 23.3 & 5463 \\
\hline \multirow[t]{4}{*}{ Scaridae } & & 9.5 & 2211 \\
\hline & $\begin{array}{l}\text { Cryptotomus } \\
\text { (C. roseus) }\end{array}$ & & 57 \\
\hline & Scarus & & 414 \\
\hline & Sparisoma & & 1740 \\
\hline Carangidae & & 6.6 & 1533 \\
\hline Gonostomatidae & & 5.3 & 1264 \\
\hline Gobiidae & & 4.9 & 1140 \\
\hline \multirow[t]{5}{*}{ Labridae } & & 4.7 & 1096 \\
\hline & $\begin{array}{l}\text { Clepticus } \\
\text { (C. parrae) }\end{array}$ & & 170 \\
\hline & Halichoeres & & 447 \\
\hline & $\begin{array}{l}\text { Thalassoma } \\
\text { (T. bifasciatum) }\end{array}$ & & 257 \\
\hline & Xyrichtys & & 222 \\
\hline Apogonidae & & 3.9 & 917 \\
\hline Clupeidae & & 3.8 & 894 \\
\hline Scombridae & & 3.8 & 890 \\
\hline Mullidae & & 3.7 & 902 \\
\hline Pomacentridae & & 3.0 & 699 \\
\hline \multirow[t]{8}{*}{ Serranidae } & & 2.2 & 510 \\
\hline & Epinephelus & & 5 \\
\hline & Hypoplectrus & & 9 \\
\hline & Liopropoma & & 31 \\
\hline & Parasphyraenops & & 1 \\
\hline & $\begin{array}{c}\text { Pseudogramma } \\
(\text { P. gregoryi) }\end{array}$ & & 57 \\
\hline & Serranus & & 362 \\
\hline & Other & & 45 \\
\hline Phosichthyidae & & 1.7 & 402 \\
\hline Lutjanidae & & 1.6 & 370 \\
\hline Sphyraenidae & & 1.5 & 361 \\
\hline Acanthuridae & & 1.4 & 331 \\
\hline Bregmacerotidae & & 1.4 & 317 \\
\hline Callionymidae & & 1.2 & 270 \\
\hline Nomeidae & & 1.1 & 262 \\
\hline Haemulidae & & 0.9 & 204 \\
\hline
\end{tabular}

Four genera are monospecific in the western central Atlantic; these are shown in parentheses.

sequence of monthly ocean color images during that time (Fig. 3).

\section{Larval fish assemblages}

Larvae from 109 fish families were collected in the plankton samples. Myctophidae larvae were the most abundant, comprising $23.3 \%$ of all larvae collected,
Table 3. Results of PERMANOVA tests among larval fish assemblages among the three different water masses, within each net type.

\begin{tabular}{|c|c|c|c|}
\hline & $\begin{array}{c}\mathrm{T} \text { - } \\
\text { statistic }\end{array}$ & $P$ value & $\begin{array}{c}\text { Unique } \\
\text { permutations }\end{array}$ \\
\hline \multicolumn{4}{|l|}{ Bongo Net (0-10 m) } \\
\hline Caribbean versus Atlantic & 2.1 & 0.001 & 999 \\
\hline Caribbean versus Plume & 1.6 & 0.005 & 999 \\
\hline Atlantic versus Plume & 1.5 & 0.006 & 988 \\
\hline \multicolumn{4}{|l|}{ MOCNESS Net $5(0-25 \mathrm{~m})$} \\
\hline Caribbean versus Atlantic & 2.2 & 0.001 & 998 \\
\hline Caribbean versus Plume & 1.1 & 0.228 & 964 \\
\hline Atlantic versus Plume & 1.5 & 0.014 & 216 \\
\hline \multicolumn{4}{|l|}{ MOCNESS Net $4(25-50 \mathrm{~m})$} \\
\hline Caribbean versus Atlantic & 1.5 & 0.003 & 999 \\
\hline Caribbean versus Plume & 1.3 & 0.069 & 961 \\
\hline Atlantic versus Plume & 1.5 & 0.014 & 218 \\
\hline \multicolumn{4}{|c|}{ MOCNESS Net $3(50-75 \mathrm{~m})$} \\
\hline Caribbean versus Atlantic & 1.7 & 0.005 & 999 \\
\hline Caribbean versus Plume & 1.1 & 0.325 & 40 \\
\hline Atlantic versus Plume & 1.2 & 0.191 & 10 \\
\hline \multicolumn{4}{|c|}{ MOCNESS Net $2(75-100 \mathrm{~m})$} \\
\hline Caribbean versus Atlantic & 1.4 & 0.025 & 998 \\
\hline Caribbean versus Plume & 1.1 & 0.287 & 40 \\
\hline Atlantic versus Plume & 1.3 & 0.179 & 10 \\
\hline
\end{tabular}

followed by Scaridae (9.5\%) and Carangidae (6.6\%) (Table 2). The 20 most abundant families encompassed $85.4 \%$ of all fish larvae collected in the plankton samples. Plume waters also had high concentrations of small jellyfish near the surface.

Initial PERMANOVA tests showed significant differences between larval fish assemblages among the three (Atlantic, Caribbean and plume) water masses $(P<0.001)$, with a significant interaction between water mass and net type $(P=0.012)$. Pairwise tests showed that differences were strongest in the shallowest nets (bongo and MOCNESS Net 5), and between the Caribbean and Atlantic water masses (Table 3).

SIMPER analyses were used to determine which families were most strongly associated with each water mass. Carangidae (SIMPER score 1.3), Scaridae (1.1) and Labridae (1.1) larvae were most influential in separating samples from the Caribbean and Atlantic water masses, with all three families more abundant in Caribbean water. Myctophidae (1.2), Nomeidae (1.5) and Scombridae (1.2) larvae best distinguished between the Caribbean and plume water masses, with all families more abundant in the plume samples. Nomeidae (1.9), Myctophidae (1.2) and Carangidae (1.4) larvae best separated the Atlantic and plume samples, with all more abundant in the plume samples. 
Figure 11. Larval concentrations (in no. per $\mathrm{m}^{3}$ ) of Myctophidae and Scaridae larvae sampled in the upper $50 \mathrm{~m}$ of the water column during two previous cruises completed in the same general study area, using a similar sampling strategy, during MarchApril 2007 (top panel), March 2008 (middle panel) and April 2009 (bottom panel). Note that the southernmost portion of the plume and the area just north of St. Croix were not sampled in 2007 and 2008 (see text).

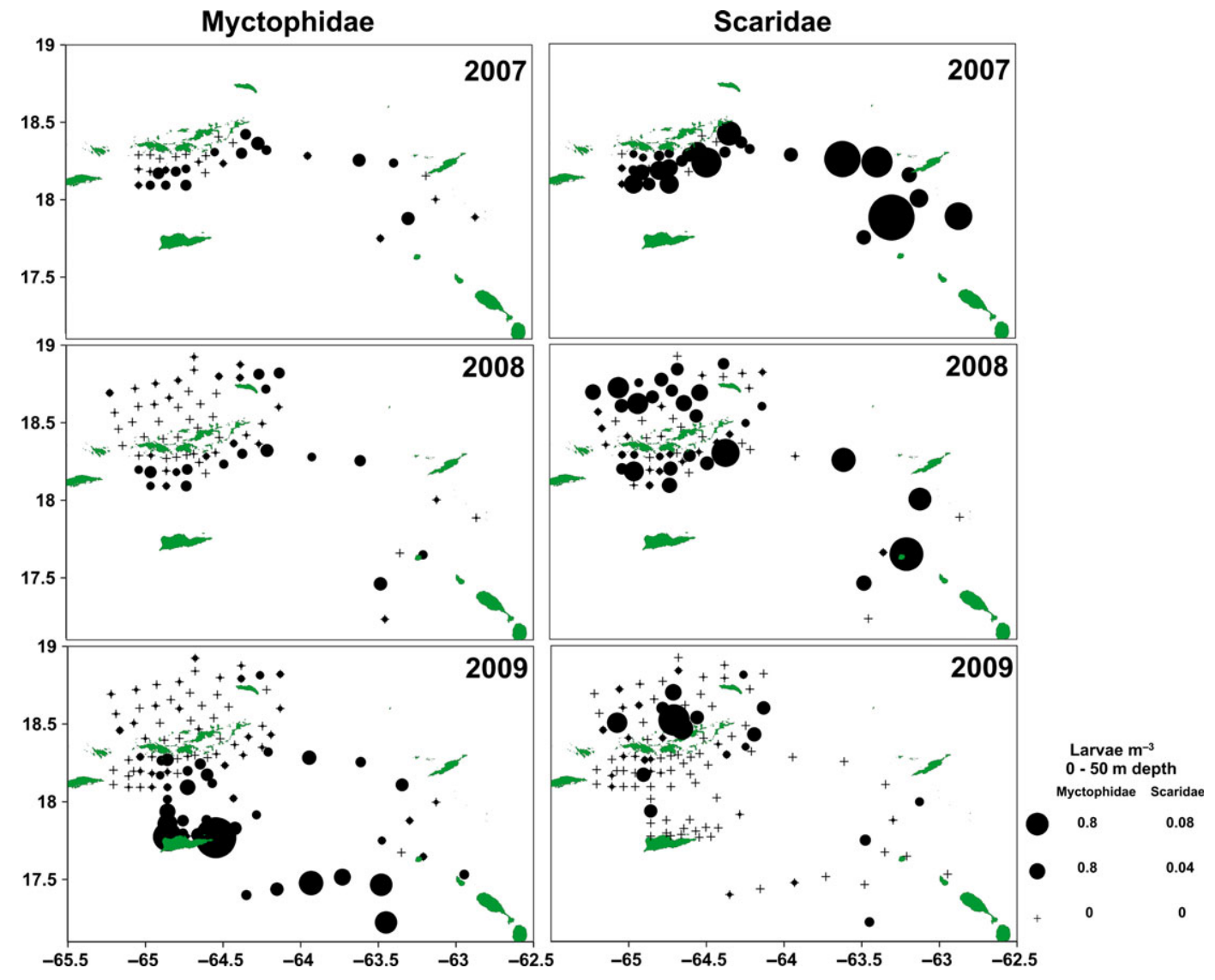

Larval fish assemblages from the plume water mass were therefore distinguished from the other water masses by higher abundances of pelagic and mesopelagic taxa, such as Myctophidae and Nomeidae. In contrast, abundances of reef- and nearshore-associated taxa such as Scaridae and Clupeidae were lowest in the plume samples (Fig. 10).

A comparison of larval abundances between 2009 and samples from two previous years (spring 2007 and 2008 cruises) showed higher abundances of Myctophidae larvae and lower abundances of Scaridae larvae in the plume region from 2009 (Fig. 11). However, because of the different objectives of each of these cruises, few stations were occupied in the southern study region during 2007 and 2008. As a result, it is difficult to draw robust conclusions regarding interannual variability.

Vertical distributions of reef-associated larvae varied by taxon and by time of sampling (Fig. 12). When all sampled stations were considered, larvae from the labrid genera Halichoeres and Xyrichtys were most abundant in the upper $\sim 50 \mathrm{~m}$ of the water column, with higher concentrations near the surface at night. Pseudogramma and Serranus (Serranidae) larvae were distributed throughout the water column, but also showed higher near-surface concentrations at night. While Scarus (Scaridae) larvae were distributed throughout the upper $50 \mathrm{~m}$, Sparisoma larvae (Scaridae) were strongly associated with the near-surface layer, with much high concentrations collected at night. Larval concentrations of two mesopelagic families were also selected for comparison. Myctophidae larvae were collected throughout the sampled depth strata, with no clear depth preference. In contrast, larvae from another mesopelagic family (Nomeidae) were associated with the upper $50 \mathrm{~m}$ of the water column. In spite of differences among families and genera, all taxa considered used the upper 10-m depth strata during some part of the day, with higher concentrations observed at night. When samples from the plume 
Figure 12. Mean larval concentrations (in no. per $\mathrm{m}^{3}$ ) with the median sampling depth for six genera from three reef-associated families, and two mesopelagic and pelagic families. Dark bars denote night samples (19.00-07.00 h), and light bars denote day samples. Standard errors are also shown. Dark bars shown on the negative portion of the x-axis denote night samples.
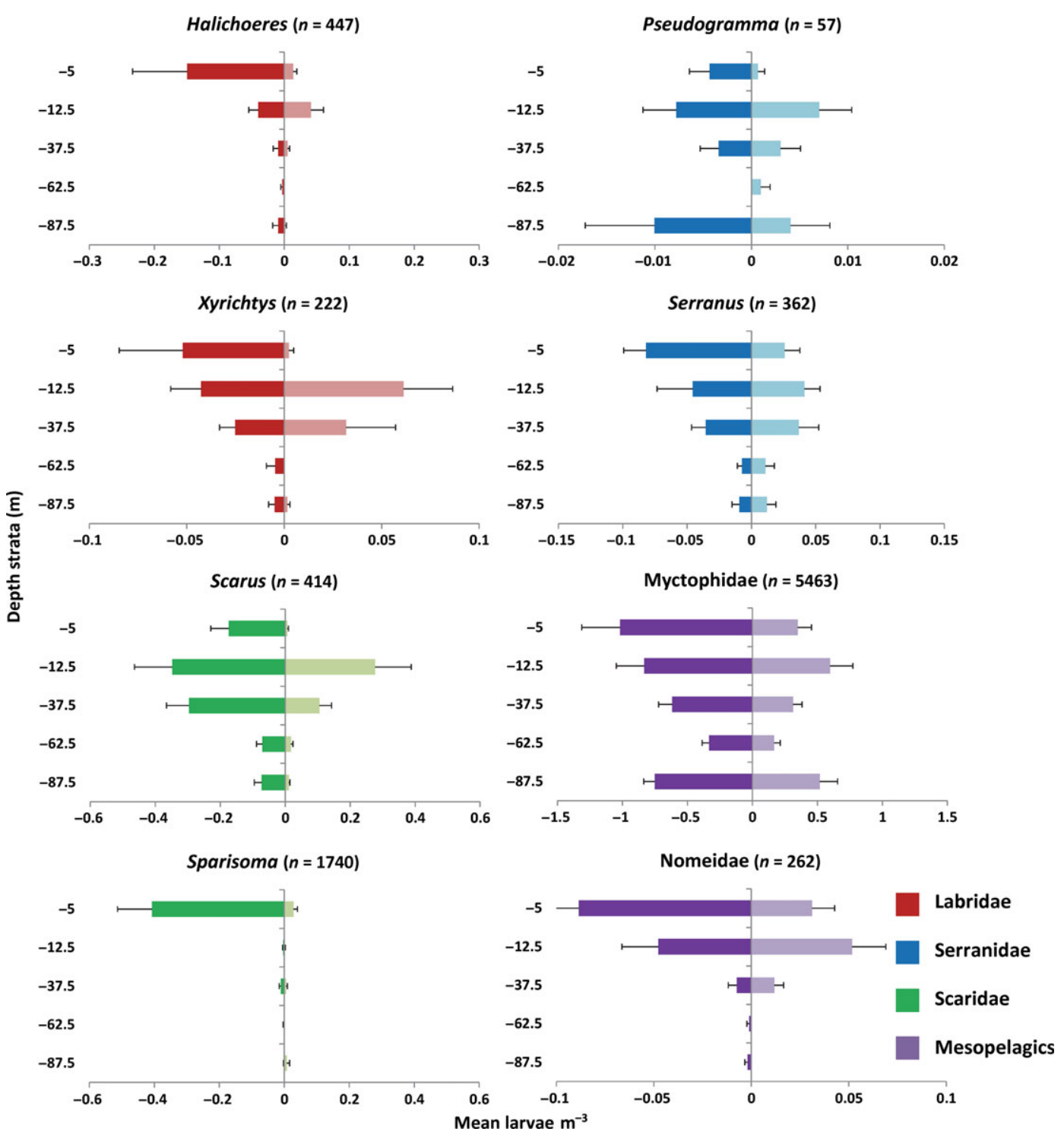

water were compared with those from Caribbean water, a strong influence on vertical larval distributions was evident (Fig. 13). Concentrations of Halichoeres, Xyrichtys, Scarus and Sparisoma larvae were much reduced in near-surface plume samples, and Serranus and Pseudogramma larvae were completely absent. In contrast, near-surface concentrations of Myctophidae and Nomeidae larvae were much greater in plume water than in Caribbean water. With the exception of Halichoeres and Pseudogramma, concentrations of larval reef fishes in the other four depth strata were generally comparable among the two water masses. However, elevated concentrations of mesopelagic larvae persisted down to approximately 50-m depth. Mean vertical profiles of chl-a fluorescence from CTD casts taken in plume versus Caribbean waters showed the strong association between the shallow, high chl-a waters at the plume stations and distinct assemblages of larval fish (Fig. 13, black solid and dashed lines).

Mean lengths of reef-associated taxa varied widely among genera, but did not vary strongly with depth (Fig. 14). Labrid larvae (Halichoeres and Xyrichtys) were the largest on average, with mean lengths of 
Figure 13. Mean larval concentrations (in no. per $\mathrm{m}^{3}$ ) with the median sampling depth for six genera from three reef-associated families, and two mesopelagic and pelagic families. Black bars denote samples from 'plume' water and gray bars denote samples from 'Caribbean' water. Standard errors are also shown, along with mean fluorescence profiles from CTD casts. The solid black series denotes plume waters, and the dashed series denotes Caribbean waters.
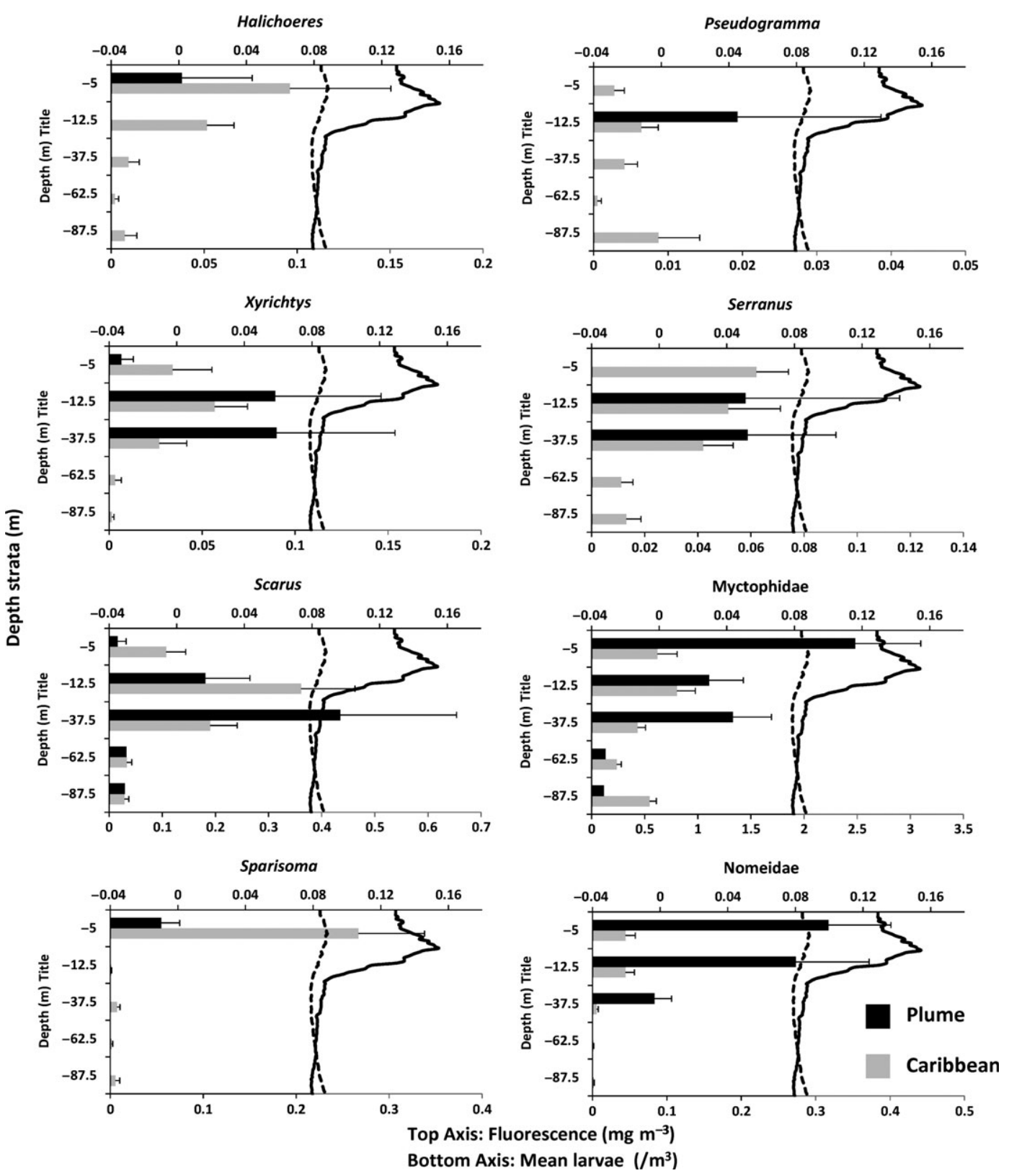

$6 \mathrm{~mm}$ and larger during much of the water column during the night. In contrast, Serranus and Scarus larvae were mostly small, with mean lengths of $<5 \mathrm{~mm}$ within all depth strata during both night and day. Pseudogramma showed some tendency for larger larvae to be located deeper in the water column, but larvae of other taxa did not show interactions between larval sizes and depth.
Settled total plankton volumes (including phytoplankton and zooplankton) from the bongo net samples were much higher in the plume samples and in Caribbean water samples (defined as $34.9<\mathrm{SSS}<36.6)$ collected just north of St. Croix than they were in the rest of the sampled area (Fig. 15). Weekly satellite ocean color imagery (Fig. 4) indicated that the plume water had moved 
Figure 14. Mean larval standard lengths $(\mathrm{mm})$ with median sampling depth for six genera from three reef-associated families. Dark bars denote night samples (19.00-07.00 h), and light bars denote day samples. Standard errors are also shown. Dark bars shown on the negative portion of the $\mathrm{x}$-axis denote night samples.
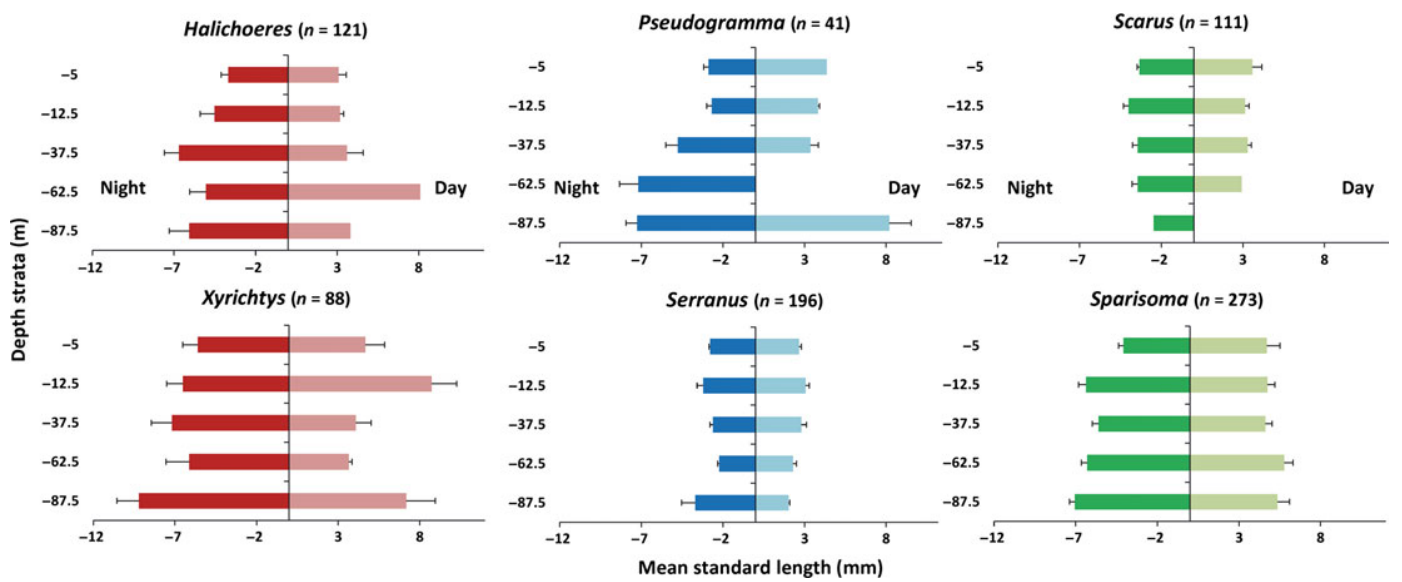

Figure 15. Settled plankton volumes $\left(\mathrm{mL} \mathrm{m}^{-3}\right)$ sampled in the upper $50 \mathrm{~m}$ of the water column during the 7-20 April 2009 cruise. The three water masses based on the salinity criteria used in Fig. 7 and Table 1 are indicated by symbol color.

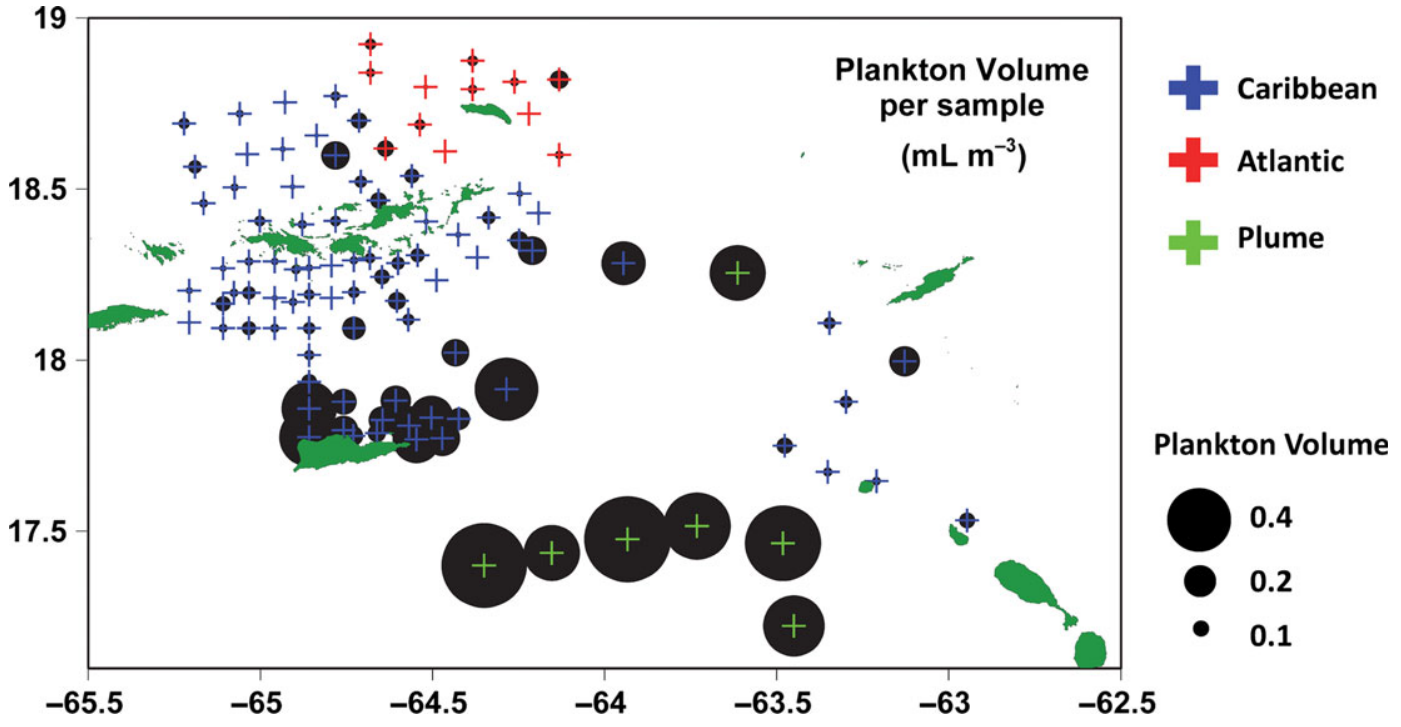

into this area by the time these stations were taken near the end of the cruise, even although they did not meet the plume salinity criterion (SSS < 34.9). Comparison of the filtered surface chl-a data from the shipboard observations with the surface bongo net-derived total plankton volumes showed a positive linear relationship with an $R^{2}$ value of 0.75 for the plume samples (Fig. 16). This shows that plume waters contained high phytoplankton as well as zooplankton concentrations. High total plankton volumes in the plume were mostly restricted to the upper two depth strata (Fig. 16). Below 50-m depth, plankton volumes among the three water mass types were very similar (Fig. 16).

Historical context of the 2009 plume event

Analysis of a monthly time series of SeaWiFS and MODIS satellite estimates of chl-a averaged over the study area $\left(17-19^{\circ} \mathrm{N}, 66-62^{\circ} \mathrm{W}\right)$ confirms that the 2009 plume event was unprecedented since at least 1998 (Fig. 17), i.e., the date when SeaWiFS observations started a robust time series of space-based chl-a observations. A strong seasonal cycle is evident, with the lowest climatological values $\left(<0.10 \mathrm{mg} \mathrm{m}^{-3}\right)$ 
Figure 16. Top: Linear correlation between settled total (phyto- and zoo-) plankton volume from bongo net samples $\left(\mathrm{mL} \mathrm{m}^{-3}\right)$ and chlorophyll-a (chl $\left.a\right)$ from surface water samples $\left(\mathrm{mg} \mathrm{m}^{-3}\right)$. Bottom: the mean settled plankton volume by sampled depth for 'plume', 'Caribbean' and 'Atlantic' waters, with standard errors shown.
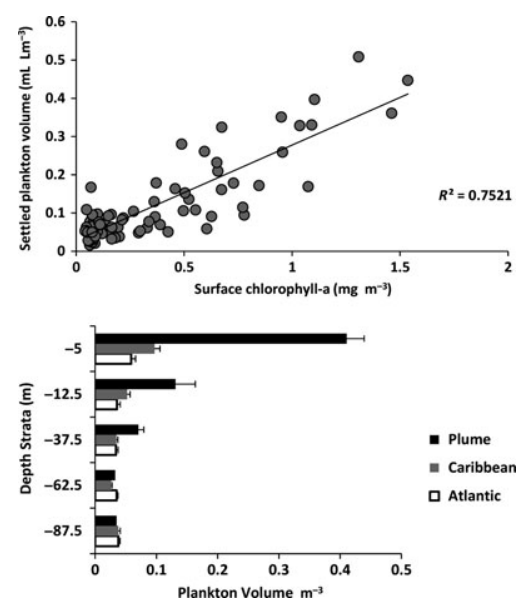

occurring in February to March, followed by a rapid rise to a peak seasonal value $\left(\sim 0.18 \mathrm{mg} \mathrm{m}^{-3}\right)$ in July. The 2009 event occurred in April to May, 2 months earlier than the climatological maximum.

Substantial interannual variability is evident in years prior to as well as after 2009. High pigment concentrations were observed in 2000 and again in 2003, shortly leading or coinciding with the time of the climatological maximum. The highest concentrations in the time series were actually recorded in 2010, coinciding in time with the climatological maximum chla.

Satellite ocean color, satellite altimetry and the Mercator Océan analysis (not shown) confirmed that the 2010 event was also the result of a NBCR delivering Amazon River water to the area, similar to what was observed in 2009. The chl-a values shown by the MODIS sensor for the cruise area during 2009 reached a peak of $0.35 \mathrm{mg} \mathrm{m}^{-3}$ in May 2009, and $0.54 \mathrm{mg} \mathrm{m}^{-3}$ in July 2010, a factor of two or more above the climatological July values of $\sim 0.18 \mathrm{mg} \mathrm{m}^{-3}$.

Figure 17. Time series of monthly average chlorophyll-a (chl-a) concentration $\left(\mathrm{mg} \mathrm{m}^{-3}\right)$ estimates from the SeaWiFS (blue) and MODIS (green) ocean color sensors. The average chl-a climatology is shown in red. Data have been averaged over the cruise domain, $17-19^{\circ} \mathrm{N}, 66-62^{\circ} \mathrm{W}$. The SeaWiFS sensor began malfunctioning during April and May 2009, and performed sporadically between that time and when it finally failed during 2010. At the time of the April 2009 cruise the chl-a concentrations were the highest seen to date in the record. However, the $2010 \mathrm{chl}-a$ peak surpassed those concentrations by nearly a factor of two.

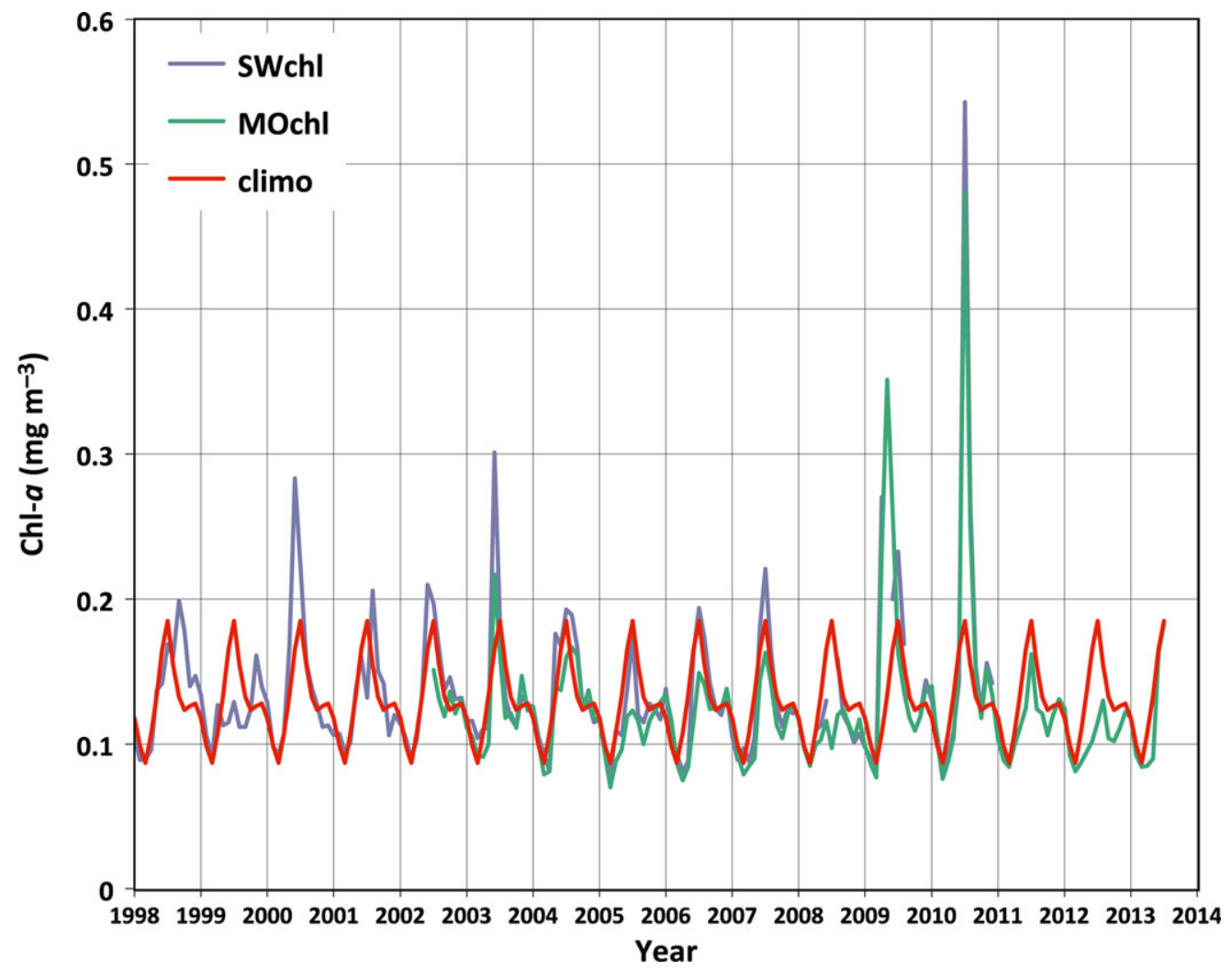

(C) 2014 John Wiley \& Sons Ltd, Fish. Oceanogr., 23:6, 472-494. 
Looking further back in time, a Coastal Zone Color Scanner (CZCS) image described by Müller-Karger et al. (1989; Plate 6) for June 1980 shows that a similar event with monthly-averaged chl-a concentrations of $>1.0 \mathrm{mg} \mathrm{m}^{-3}$ occurred in the region. No other comparable event was observed in the rest of the 1978-1986 CZCS time series.

\section{DISCUSSION}

A large bolus of Amazon River water was found in the northeastern Caribbean Sea during April and May 2009, several months earlier and farther to the north than is normally observed in the area. Examination of satellite altimeter observations and results from a dataassimilating numerical model confirmed that the Amazon River water was delivered to the Caribbean via advection by a NBCR that set up a positive westto-east sea level slope across the Lesser Antilles island arc. This in turn drove a strong northward geostrophic jet with speeds $>25 \mathrm{~cm} \mathrm{~s}^{-1}$ inside the Caribbean Sea, just west of the Lesser Antilles. As the Amazon water entered the Caribbean Sea, it spread to the north and northwest at $11-26 \mathrm{~cm} \mathrm{~s}^{-1}$, as observed both in a sequence of satellite ocean color images and satellitetracked surface drifter trajectories.

Shipboard observations showed that the April 2009 plume was low in SSS, and high in SST, chl- $a$ and dissolved oxygen compared with surrounding waters (Table 1). This was consistent with previous observations in river plumes (Hu et al., 2004; Ffield, 2007). The high phytoplankton concentrations observed both in situ and using synoptic remotely-sensed ocean color imagery help explain the high surface dissolved oxygen concentrations in the plume relative to surrounding waters, in spite of the warmer temperatures of the plume. Oxygen profiles showed depletion of dissolved oxygen below the plume. Remineralization of materials sinking from surface plumes has been shown to contribute to the low dissolved oxygen and high dissolved nitrate concentrations observed in Subtropical Underwater (SUW) entering the Caribbean Sea (Montes et al., 2013a,b). The SUW is likely strongly imprinted by the processes of remineralization of materials raining down through the water column from the Amazon River plume.

In the present study, total plankton volumes and surface chl-a observed within plume waters at the time of sampling were shown to be much higher than surrounding waters, suggesting an influx of nutrients to plume waters at some stage since formation. Remotely-sensed data showed a plankton bloom within the plume waters appearing to intensify as a result of an upwelling-favorable cyclonic circulation which developed in the eastern Caribbean west of the Lesser Antilles. The observed plankton communities sampled within the plume waters were therefore likely a product of both the characteristics of the original Amazon River water mass and influxes of nutrients owing to upwelling in the eastern Caribbean, which further stimulated plankton growth.

The type of plankton found in river plumes can vary with time. Newly-formed Amazon plume waters have previously been reported to be generally high in iron and silicate, but deficient in nitrate and phosphate. This resulted in a phytoplankton community dominated by diatoms, with total plankton volumes similar to or less than surrounding oceanic waters (Ryther et al., 1967; Hulburt and Corwin, 1969). Other previous studies have demonstrated offshore entrainment of coastal plankton species as the Amazon River plume spreads into the Atlantic (Ketchum and Ryther, 1966; Ryther et al., 1967; Hulburt and Corwin, 1969; Borstad, 1982a,b; Müller-Karger et al., 1989; Subramaniam et al., 2008).

The larval fish assemblages observed during April 2009 were distinct between the three water masses identified (Caribbean, Atlantic and plume). In spite of the coastal equatorial origin of the Amazon plume water at the time of its formation, when it would have been expected to contain coastal plankton species including diatoms, the larval fish assemblages sampled months later in the near-surface waters of the northeastern Caribbean within the plume were dominated by mesopelagic and pelagic fish species. Comparable results have been observed elsewhere, where riverine and coastal waters have been sampled several months after offshore entrainment. For example, Muhling et al. (2007) reported on a study of eddy features several hundred miles off the west Australian coast. One eddy had entrained coastal water approximately 4 months previously and subsequently moved offshore. Some of the sampled phytoplankton were still identifiable as 'coastal', but all of the larval fish were mesopelagic.

The typical pelagic larval duration of coastal and reef-associated fish species may be on the order of weeks, and (with the exception of leptocephalus larvae) seldom exceeds a month in the absence of suitable settlement habitat (Brothers et al., 1983; Wellington and Victor, 1989). During 2009, as the Amazon water moved offshore and northwestward toward the Caribbean Sea, trapped within the NBCR circulation and northward advection, mesopelagic larvae were likely entrained into the water mass. Outside the plume, reef fish larvae were abundant in the upper 
$10 \mathrm{~m}$ of the water column, particularly at night. These high concentrations were absent from the upper water column within plume waters, suggesting exclusion of these larvae from their usual vertical habitat.

Larval fish assemblage studies in the Caribbean and surroundings are comparatively rare. Muhling et al. (2013) described shoreward entrainment of mesopelagic fish larvae against the Yucatan Peninsula and the dominance of these taxa in offshore samples, and demonstrated the important role of eddies and gyres in larval retention and dispersion. Richards (1984) also showed the ubiquitous occurrence of myctophid fish larvae in offshore Caribbean waters throughout the year.

Low salinity, high chlorophyll plumes have significant ecological implications for larval fish in the northeastern Caribbean Sea. Studies in temperate ecosystems have found that river plumes may be beneficial to growth and survival of larvae. High primary and secondary production within plume waters and plume boundaries have been linked to improved feeding conditions (Grimes and Kingsford, 1996), and enhanced larval growth (Lang et al., 1994). Larval sciaenids collected within Mississippi River outflow in the Gulf of Mexico fed more successfully than those from outside plume waters, owing to their ability to target a wide variety of prey items (Govoni and Chester, 1990). However, coral reef fish larvae from the western central Atlantic appear to feed very specifically (Llopiz and Cowen, 2009), and may rely primarily on only one or two zooplankton taxa throughout much of their larval stage. Their ability to adapt to potentially enhanced but unfamiliar feeding conditions within a river plume such as that encountered in 2009 is therefore uncertain. Sponaugle and Pinkard (2004) found that the passage of NBCRs past Barbados resulted in lower growth of T. bifasciatum (Labridae) larvae. They speculated that this may have been as a result of disruption of the usual prey field, and to potentially reduced visibility within turbid plume waters, which can affect usual prey capture behaviors (Chesney, 1989).

Changes in conditions for larval fish feeding, growth and survival by the plume described in this study may have important consequences for recruitment of local species, including commercially important snappers, groupers and parrotfishes. Data on recruitment and stock sizes in the Caribbean region are sparse, and any impacts are consequently difficult to measure (Valle-Esquivel and Diaz, 2003; Salas et al., 2007). In addition, settlement and subsequent recruitment is influenced by multiple processes, on a variety of temporal and spatial scales.
As a result, post-larval settlement may not always correspond closely to observed oceanographic events (Cowen et al., 2003).

Of the commercially important fish species currently assessed, peak spawning seasons range from a few months, such as with red hind (Epinephelus guttatus) which spawns from December through to February, and queen snapper (Etelis oculatus) which spawns from November to December, to species which spawn throughout much of the year, such as silk snapper (Lutjanus vivanus) and yellowtail snapper (Ocyurus chrysurus) (Munro et al., 1973; Gobert et al., 2005; Nemeth, 2005; Graham et al., 2008). Many of the parrotfishes (Scaridae) spawn in the spring (Munro et al., 1973), as evidenced by their high abundance in larval collections from this study. Any potential impacts of the anomalous Amazon River plume event of spring 2009 on the survival of larvae, and their ultimate recruitment, would depend on a temporal overlap between the plume water and the spawning seasons of the local reef fish species.

In conclusion, this study documents the occurrence of a low salinity, high chlorophyll plume of Amazon River water impinging on the northeastern Caribbean during spring 2009. Samples from within the plume contained high concentrations of plankton, including abundant larvae of mesopelagic and pelagic fishes. This water mass may have displaced the more typical Caribbean assemblage of reef fish larvae within the near-surface layer.

An important question is whether the influx of Amazon River water and the subsequently altered water properties in the northeastern Caribbean during 2009 (and again in 2010) are indicative of a secular change in either the regional circulation or the frequency, size, and/or variability in dispersal patterns of NBCRs in the tropical and subtropical western Atlantic. The impact of recurrent events of this type could be even more potentially damaging to the ecology of the eastern Caribbean than single isolated events as have been seen in the past. The ecological effects on the survival and recruitment of economically important local reef fishes such as snappers, groupers and parrotfishes may be significant, but are hard to quantify. Future work will use satellite altimetry and ocean color observations, in conjunction with the Mercator Océan global ocean reanalysis, to address the question of whether there has indeed been a trend in the regional circulation patterns linking the Amazon River delta and the Caribbean Sea, and what if any changes may have occurred in the large-scale forcing to cause an increase in the likelihood of these extreme river plume events. 


\section{ACKNOWLEDGEMENTS}

The authors gratefully acknowledge the Officers and crew of the NOAA Ship Nancy Foster, and all of our seagoing, technical and laboratory support colleagues for their invaluable assistance in the acquisition and analysis of the data reported herein. We acknowledge the important contributions of the SEFSC Early Life History laboratory, especially Aki Shiroza, Alexandra Ender and Sarah Privoznik, for field collections, sample processing and larval fish identifications. We thank the Global Drifter Center for supplying the satellite-tracked surface drifters and providing their trajectory data to us. We acknowledge the mission scientists and associated NASA personnel for the production of the SeaWiFS and MODIS time series data used in this research effort. Output from the operational hindcast global ocean product (Prototype SYstème) was provided through a collaborative agreement with Mercator Océan. The Mercator Océan global operational forecasting system, as part of the European Marine Core Service, is supported by the European Community's Seventh Framework Programme FP7/2007-2013 under Grant Agreement no. 218812 (MyOcean). The authors thank Fabrice Hernandez for his assistance with Mercator Océan products. The comments and suggestions from two anonymous reviewers greatly improved this manuscript and they are gratefully acknowledged. This work was funded by NOAA's Coral Reef Conservation Program (CRCP) USVI Larval Supply and Distribution Study, with additional support contributed by NOAA's Atlantic Oceanographic and Meteorological Laboratory (AOML) and Southeast Fisheries Science Center (SEFSC). Ship time was provided by NOAA's Office of Ocean and Atmospheric Research (OAR). Partial support for Frank Muller-Karger was provided by NASA Grant NNX11AP76G, awarded to Roffer's Ocean Fishing Forecasting Service. This research was carried out in part under the auspices of the Cooperative Institute for Marine and Atmospheric Studies (CIMAS), a Cooperative Institute of the University of Miami and the National Oceanic and Atmospheric Administration (NOAA), Cooperative Agreement \#NA10OAR4320143.

\section{REFERENCES}

Acker, J.G. and Leptoukh, G. (2007) Online analysis enhances use of NASA earth science data. EOS Trans. AGU 88:1417.

Anderson, M.J. (2001) A new method for non-parametric multivariate analysis of variance. Austral Ecol. 26:32-46.

Barnier, B., Madec, G., Penduff, T., et al. (2006) Impact of partial steps and momentum advection schemes in a global ocean circulation model at eddy-permitting resolution. Ocean Dyn. 56:543-567 doi:10.1007/s10236-006-0082-1.

Booth, D.J. and Beretta, G.A. (1994) Seasonal recruitment, habitat associations and survival of pomacentrid reef fish in the US Virgin Islands. Coral Reefs 13:81-89.

Borstad, G.A. (1982a) The influence of the meandering Guiana Current and Amazon River discharge on surface salinity near Barbados. J. Mar. Res. 40:421-434.

Borstad, G.A. (1982b) The influence of the meandering Guiana Current and Amazon River on surface conditions near Barbados - temporal variations of Trichodesmium (Cyanophyta) and other plankton. J. Mar. Res. 40:435-452.

Brothers, E.B., Williams, D.M. and Sale, P.F. (1983) Length of larval life in twelve families of fishes at "One Tree Lagoon”, Great Barrier Reef, Australia. Mar. Biol. 76: 319-324.

Bruce, J.G., Kerling, J.L. and Beatty, W.H.III (1985) On the north Brazilian eddy field. Prog. Oceanogr. 14:57-63.

del Castillo, C.E., Coble, P.G., Morell, J.M., Lopez, J.M. and Corredor, J.E. (1999) Analysis of the optical properties of the Orinoco River plume by absorption and fluorescence spectroscopy. Mar. Chem. 66:35-51.

Cherubin, L.M. and Richardson, P.L. (2007) Caribbean Current variability and the influence of the Amazon and Orinoco fresh water plumes. Deep Sea Res. I 54:1451-1473.

Chesney, E.J. Jr (1989) Estimating the food requirements of striped bass larvae Morone saxatilis: effects of light, turbidity and turbulence. Mar. Ecol. Prog. Ser. 53:191-200.

Clarke, K.R. (1993) Non-parametric multivariate analyses of changes in community structure. Aust. J. Ecol. 18:117-143.

Clarke, K.R. and Gorley, R.N. (2006) PRIMER v6: User Manual/Tutorial. Plymouth: PRIMER-E.

Corredor, J.E. and Morell, J. (2001) Seasonal variation of physical and biogeochemical features in eastern Caribbean surface water. J. Geophys. Res. 106:4517-4525.

Cowen, R.K., Sponaugle, S., Paris, C.B., Fortuna, J.L., Lwiza, K.M.M. and Dorsey, S. (2003) Impact of North Brazil Current rings on local circulation and coral reef fish recruitment to Barbados, West Indies. In: Interhemispheric Water Exchange in the Atlantic Ocean. G.J. Goni \& P. Malanotte-Rizzoli (eds) Amsterdam: Elsevier Oceanography Series 68, pp. 443-462.

Drévillon, M. et al. (2008) The GODAE/Mercator-Ocean global ocean forecasting system: results, applications and prospects. J. Oper. Oceanogr. 1:51-57.

Ffield, A. (2005) North Brazil current rings viewed by TRMM Microwave Imager SST and the influence of the Amazon Plume. Deep Sea Res. I 52:137-160.

Ffield, A. (2007) Amazon and Orinoco River plumes and NBC rings: bystanders or participants in hurricane events? J. Clim. 20:316-333.

Fratantoni, D.M. and Richardson, P.L. (2006) The evolution and demise of North Brazil Current rings. J. Phys. Oceanogr. 36:1241-1264.

Gobert, B., Guillou, A., Murray, P. et al. (2005) Biology of queen snapper (Etelis oculatus: Lutjanidae) in the Caribbean. Fish. Bull. 103:417-425.

Goni, G.J. and Johns, W.E. (2001) A census of North Brazil Current Rings observed from TOPEX/POSEIDON altimetry: 1992-1998. Geophys. Res. Lett. 29:1-4.

Gordon, A.L. (1967) Circulation of the Caribbean Sea. J. Geophys. Res. 72:6207-6223. 
Govoni, J.J. and Chester, A.J. (1990) Diet composition of larval Leiostomus xanthurus in and about the Mississippi River plume. J. Plankton Res. 12:819-830.

Graham, R.T., Carcamo, R., Rhodes, K.L., Roberts, C.M. and Requena, N. (2008) Historical and contemporary evidence of a mutton snapper (Lutjanus analis Cuvier, 1828) spawning aggregation fishery in decline. Coral Reefs 27:311-319.

Grimes, C.B. and Kingsford, M.J. (1996) How do riverine plumes of different sizes influence fish larvae: do they enhance recruitment? Mar. Freshw. Res. 47:191-208.

Grothues, T.M. and Cowen, R.K. (1999) Larval fish assemblages and water mass history in a major faunal transition zone. Cont. Shelf Res. 19:1171-1198.

Hare, J.A., Fahay, M.P. and Cowen, R.K. (2001) Springtime ichthyoplankton of the slope region off the north-eastern United States of America: larval assemblages, relation to hydrography and implications for larval transport. Fish. Oceanogr. 10:164-192.

Hu, C., Montgomery, E.T., Schmitt, R.W. and Müller-Karger, F.E. (2004) The dispersal of the Amazon and Orinoco River water in the tropical Atlantic and Caribbean Sea: observation from space and S-PALACE floats. Deep Sea Res. II 51:1151-1171.

Hulburt, E.M. and Corwin, N. (1969) Influence of the Amazon River outflow on the ecology of the western tropical Atlantic. III. The planktonic flora between the Amazon River and the Windward Islands. J. Mar. Res. 27:55-72.

Johns, W.E., Lee, T.N., Schott, F., Zantopp, R.J. and Evans, R.H. (1990) The North Brazil Current retroflection: seasonal structure and eddy variability. J. Geophys. Res. 95:22, 103$22,120$.

Johns, E., Wilson, W.D. and Molinari, R.L. (1999) Direct observations of velocity and transport in the passages between the Intra-Americas Sea and the Atlantic Ocean, 1984-1996. J. Geophys. Res. 104:25805-25820.

Johns, W.E., Townsend, T.L., Fratantoni, D.M. and Wilson, W.D. (2002) On the Atlantic inflow to the Caribbean Sea. Deep Sea Res. I 49:211-243.

Kadison, E., Nemeth, R.S., Herzlieb, S. and Blondeau, J. (2006) Temporal and spatial dynamics of Lutjanus cyanopterus (Pisces: Lutjanidae) and L. jocu spawning aggregations in the United States Virgin Islands. Rev. Biol. Trop. 54:69-78.

Kelble, C.R., Ortner, P.B., Hitchcock, G.L. and Boyer, J.N. (2005) Attenuation of photosynthetically available radiation (PAR) in Florida Bay: potential for light limitation of primary producers. Estuaries 28:560-571.

Kelly, P.S., Lwiza, K.M.M., Cowen, R.K. and Goni, G.J. (2000) Low-salinity pools at Barbados, West Indies: their origin, frequency, and variability. J. Geophys. Res. 105:19, 699-19, 708.

Ketchum, B.H. and Ryther, J.H. (1966) Biological, Chemical, and Radiochemical Studies of Marine Plankton, Reference No. 6618. Woods Hole: Woods Hole Oceanographic Institution.

Lang, K.L., Grimes, C.B. and Shaw, R.F. (1994) Variations in the age and growth of yellowfin tuna larvae, Thunnus albacares, collected about the Mississippi River plume. Environ. Biol. Fishes 39:259-270.

Llopiz, J.K. and Cowen, R.K. (2009) Variability in the trophic role of coral reef fish larvae in the oceanic plankton. Mar. Ecol. Prog. Ser. 381:259-272.

López, R., del Castillo, C.E., Miller, R.L., Salisbury, J. and Wisser, D. (2012) Examining organic carbon transport by the Orinoco River using SeaWiFS imagery. J. Geophys. Res. 117:13pp doi:10.1029/2012JG001986.

Lumpkin, R. and Pazos, M. (2007) Measuring surface currents with Surface Velocity Program drifters: the instrument, its data, and some recent results. In Lagrangian Analysis and Prediction of Coastal and Ocean Dynamics. A. Griffa, A.D. Kirwan, A. Mariano, T. Özgökmen \& T. Rossby (eds) Cambridge: Cambridge University Press, pp. 39-67.

Madec, G. and the NEMO team (2008) NEMO ocean engine. In: Note du Pole de Modélisation. Institut Pierre-Simon Laplace (IPSL), France, No. 27, ISSN No. 1288-1619.

Montes, E., Altabet, M., Muller-Karger, F.E., Scranton, M., Lorenzoni, L. and Astor, Y. (2013a) Biogenic nitrogen gas production at the oxic-anoxic interface in the Cariaco Basin, Venezuela. Biogeosciences 10:267-279.

Montes, E., Thunell, R., Muller-Karger, F.E. et al. (2013b) Sources of $\delta 15 \mathrm{~N}$ variability in sinking particulate nitrogen in the Cariaco Basin, Venezuela. Deep Sea Res. II http://www. sciencedirect.com/science/article/pii/S0967064513000076. [accessed September 24, 2014].

Muhling, B.A., Beckley, L.E. and Olivar, M.P. (2007) Ichthyoplankton assemblage structure in two meso-scale Leeuwin Current eddies, eastern Indian Ocean. Deep Sea Res. II 54:1113-1128.

Muhling, B.A., Smith, R.H., Vasquez-Yeomans, L. et al. (2013) Larval fish assemblages and mesoscale oceanographic structure along the Mesoamerican Barrier Reef System. Fish. Oceanogr. 22:409-428.

Müller-Karger, F. (1993) River discharge variability including satellite-observed plume-dispersal patterns. In: Climatic Changes in the Intra-Americas Sea. G. Maul (ed.) Pub. Edward Arnold Publishers Ltd., New York, pp. 162-192.

Müller-Karger, F.E., McClain, C.R. and Richardson, P.L. (1988) The dispersal of the Amazon's water. Nature 333:56-59.

Müller-Karger, F.E., McClain, C.R., Fisher, T.R., Esais, W.E. and Varela, R. (1989) Pigment distribution in the Caribbean Sea: observations from space. Progr. Oceanogr. 23:23-64.

Müller-Karger, F.E., Richardson, P.L. and McGillicuddy, D. (1995) On the offshore dispersal of the Amazon's Plume in the North Atlantic. Deep Sea Res. I 42:2127-2137.

Munro, J.L., Gaut, V.C., Thompson, R. and Reeson, P.H. (1973) The spawning seasons of Caribbean reef fishes. J. Fish Biol. 5:69-84.

Murphy, S.J. and Hurlburt, H.E. (1999) The connectivity of eddy variability in the Caribbean Sea, the Gulf of Mexico, and the Atlantic Ocean. J. Geophys. Res. 104: $1431-1453$.

Nemeth, R.S. (2005) Population characteristics of a recovering US Virgin Islands red hind spawning aggregation following protection. Mar. Ecol. Prog. Ser. 286:81-97.

Odriozola, A.L., Varela, R., Hu, C., Astor, Y., Lorenzoni, L. and Müller-Karger, F.E. (2007) On the absorption of light in the Orinoco River plume. Cont. Shelf Res. 27:1447-1464 doi 10. 1016/j.csr.2007.01.012.

O'Reilly, J.E. et al. (2000) Ocean color chlorophyll a algorithms for SeaWiFS, OC2, and OC4: version 4. In: SeaWiFS Postlaunch Calibration and Validation Analyses, Part 3. NASA Tech. Memo. 2000-206892, Vol. 11. S.B. Hooker \& E.R. Firestone (eds) Greenbelt: NASA Goddard Space Flight Center, pp. 9-23.

Pham, D.T., Verron, J. and Roubaud, M.-C. (1998) A singular evolutive extended Kalman filter for data assimilation in oceanography. J. Mar. Sys. 16:323-340. 
Richards, W.J. (1984) Kinds and abundances of fish larvae in the Caribbean Sea and adjacent areas. NOAA Tech. Rep. Special Scientific Report Fisheries (SSRF) 776:55.

Richards, W.J. (2005) Early Stages of Atlantic Fishes: An Identification Guide for the Western Central North Atlantic, Vols. 1 and 2. CRC Press, Taylor \& Francis Group: Boca Raton, FL.

Ryther, J.H., Menzel, D.W. and Corwin, N. (1967) Influence of the Amazon River outflow on the ecology of the western tropical Atlantic. I. Hydrography and nutrient chemistry. J. Mar. Res. 25:69-83.

Salas, S., Chuenpagdee, R., Seijo, J.C. and Charles, A. (2007) Challenges in the assessment and management of small-scale fisheries in Latin America and the Caribbean. Fish. Res. $87: 5-16$.

Salisbury, J., Vandemark, D., Campbell, J. et al. (2011) Spatial and temporal coherence between Amazon River discharge, salinity, and light absorption by colored organic carbon in western tropical Atlantic surface waters. J. Geophys. Res. 116: $\mathrm{COOHO2.}$

Shulman, M.J. and Ogden, J.C. (1987) What controls tropical reef fish populations: recruitment or benthic mortality? An example in the Caribbean reef fish Haemulon flavolineatum. Mar. Ecol. Prog. Ser. 39:233-242.

Smith, R.H. (2009) NF0903 Cruise Report. URL ftp://ftp.aoml. noaa.gov/phod/pub/rsmith/CRER/NF0903/report/NF0903_ cruise_report.pdf [accessed 15 May 2014].
Sponaugle, S. and Pinkard, D.R. (2004) Impact of variable pelagic environments on natural larval growth and recruitment of the reef fish Thalassoma bifasciatum. J. Fish Biol. 64:34-54.

Subramaniam, A. et al. (2008) Amazon River enhances diazotrophy and carbon sequestration in the tropical North Atlantic Ocean. Proc. Natl Acad. Sci. USA 105:1046010465.

Timmermann, R., Goosse, H., Madec, G., Fichefet, T., Ethe, C. and Duliere, V. (2004) On the representation of high latitude processes in the ORCA-LIM global coupled sea iceocean model. Ocean Modell. 6:175-201.

Tranchant, B., Testut, C.-E., Renault, L., Ferry, N., Birol, F. and Brasseur, P. (2008) Expected impact of the future SMOS and aquarius ocean surface salinity missions in the mercator ocean operational systems: new perspectives to monitor ocean circulation. Rem. Sens. Env. 112:1476-1487.

Valle-Esquivel, M. and Diaz, G. (2003) Preliminary Estimation of Reported Landings, Expansion Factors and Expanded Landings for the Commercial Fisheries of the United States Virgin Islands. Sustainable Fisheries Division Contribution SFD-2003-0027. NOAA NMFS, Silver Spring, MD, 51 pp.

Wellington, G.M. and Victor, B.C. (1989) Planktonic larval duration of one hundred species of Pacific and Atlantic damselfishes (Pomacentridae). Mar. Biol. 101:557-567.

Wilson, W.D. and Johns, W.E. (1997) Velocity structure and transport in the Windward Islands passages. Deep Sea Res. I 49:211-243. 